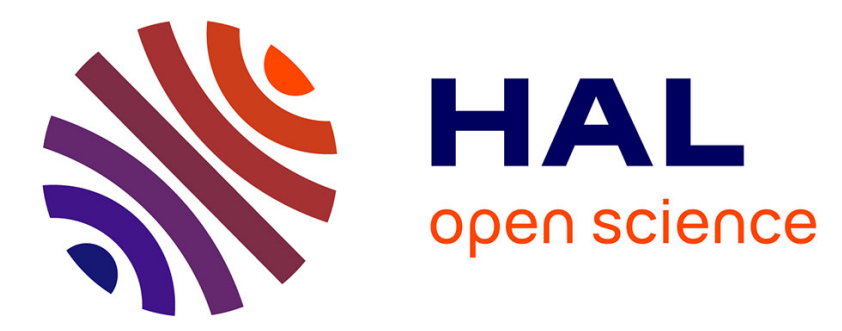

\title{
Structural record of Lower Miocene westward motion of the Alboran Domain in the Western Betics, Spain
}

Gianluca Frasca, Frédéric Gueydan, Jean-Pierre Brun

\section{To cite this version:}

Gianluca Frasca, Frédéric Gueydan, Jean-Pierre Brun. Structural record of Lower Miocene westward motion of the Alboran Domain in the Western Betics, Spain. Tectonophysics, 2015, 657, pp.1-20. 10.1016/j.tecto.2015.05.017 . insu-01163695

\section{HAL Id: insu-01163695 https://hal-insu.archives-ouvertes.fr/insu-01163695}

Submitted on 15 Jun 2015

HAL is a multi-disciplinary open access archive for the deposit and dissemination of scientific research documents, whether they are published or not. The documents may come from teaching and research institutions in France or abroad, or from public or private research centers.
L'archive ouverte pluridisciplinaire HAL, est destinée au dépôt et à la diffusion de documents scientifiques de niveau recherche, publiés ou non, émanant des établissements d'enseignement et de recherche français ou étrangers, des laboratoires publics ou privés. 
Structural record of Lower Miocene westward motion of the Alboran Domain in the Western Betics, Spain.

Gianluca Frasca $^{1,2 *}$, Frédéric Gueydan ${ }^{2}$, Jean-Pierre Brun ${ }^{1}$

${ }^{1}$ Géosciences Rennes, Université Rennes 1, UMR 6118 CNRS, Campus de Beaulieu, 35042 Rennes Cedex, France

${ }^{2}$ Géosciences Montpellier, Université Montpellier 2, UMR 5243 CNRS/INSU, Place E. Bataillon, CC60, 34093 Montpellier Cedex, France

*Corresponding author e-mail and telephone number: gianluca.frasca@univ-rennes1.fr; +33649326203

\section{ABSTRACT}

In the framework of the Africa-Europe convergence, the Mediterranean system presents a complex interaction between subduction rollback and upper-plate deformation during the Tertiary. The western end of the system shows a narrow arcuate geometry across the Gibraltar arc, the Betic-Rif belt, in which the relationship between slab dynamics and surface tectonics is not well understood. The present study focuses on the Western Betics, which is characterized by two major thrusts: 1/ the Internal/External Zone Boundary limits the metamorphic domain (Alboran Domain) from the fold-and-thrust belts in the External Zone; 2/ the Ronda Peridotites Thrust allows the juxtaposition of a strongly attenuated lithosphere section with large bodies of sub-continental mantle rocks on top of upper crustal rocks. New structural data show that two major E-W strike-slip corridors played a major role in the deformation pattern of the Alboran Domain, in which E-W dextral strike-slip faults, N60 ${ }^{\circ}$ thrusts and $\mathrm{N} 140^{\circ}$ normal faults developed simultaneously during dextral strike-slip simple shear. Olistostromic sediments of Lower Miocene age were deposited and deformed in this tectonic context and hence provide an age estimate for the inferred continuous westward translation of the Alboran Domain that is accommodated by an E-W lateral (strike-slip) ramp and a $\mathrm{N} 60^{\circ}$ frontal thrust. The crustal emplacement of large bodies of sub-continental mantle may occur at the onset of this westward thrusting in the Western Alboran domain. At lithosphere-scale, we interpret the observed deformation pattern as the subduction upper-plate expression of a lateral slab tear and its westward propagation since Lower Miocene.

KEYWORDS: Western Betics; strike-slip corridors; thrust and lateral ramps; slab tearing 


\section{1/ Introduction}

In the Mediterranean, the correlation between P-wave tomographic models that reveal the present-day 3D complexity of slab geometry and surface geology has permitted to reconstruct the subduction upper-plate deformation during slab rollback. The trench curvature that progressively increased during trench retreat (Faccenna et al., 2004; Rosenbaum et al., 2004) is laterally accommodated by slab tearing along northern Africa (Wortel and Spakman, 2000), in Central Mediterranean, and along western Anatolia, in the Aegean (Brun and Sokoutis, 2010; Jolivet et al., 2013), explaining the progressive formation of the Calabrian and Hellenic arcs, respectively.

The western termination of the Mediterranean realm in the Alboran-Gibraltar arc domain is far less understood. The diffuse plate boundary between Africa and Eurasia is an arcuate system defined by two Alpine belts, the Betics in Spain and the Rif in Morocco (Chalouan et al., 2008; Crespo-Blanc and Frizon de Lamotte, 2006; Platt et al., 2013) that developed during the convergence between Africa and Eurasia plates (Dewey et al., 1989; Mazzoli and Helman, 1994; Rosenbaum et al., 2002; Schettino and Turco, 2011; Vissers and Meijer, 2012). The formation of the Gibraltar arc is viewed as extensional collapse of a previous existing belt (e.g. Platt et al., 1998), driven by i) continental lithospheric delamination, with different direction (Docherty and Banda, 1995; García-Dueñas et al., 1992; Seber et al., 1996), and/or ii) slab rollback (Faccenna et al., 2004; Frizon de la Motte et al., 2009; Lonergan and White, 1997; Rosenbaum et al., 2004; Royden, 1993), with also possible lateral accommodation by continental lithosphere delamination in Morocco (Fadil et al., 2006; Pérouse et al., 2010).

The earlier tomographic images (Blanco and Spakman, 1993) have lead to various contrasted interpretations (e.g. comment to Gutscher et al., 2002, by Platt et al., 2003c). The most recent tomographic models (Bezada et al., 2013; Bonnin et al., 2014, Thurner et al., 2014, Palomeras et al., 2014) display a very localized, subvertical, well-resolved high Vp anomaly below the Gibraltar arc, which further suggests subduction rollback as the geodynamical process responsible for the arcuate belt along the plate boundary. However, interpretations that significantly differ in terms of timing, direction of displacement and amount of slab rollback have been proposed (Faccenna et al., 2004; Gueguen et al., 1998; Gutscher et al., 2012; Spakman and Wortel, 2004; Vergés and Fernández, 2012).

The present study aims at providing geological and structural constraints on the timing and direction of displacement of the Alboran Domain in the Western Betics. In this paper, we 
first describe the geological setting of the Betic-Rif belt and more specifically the northern branch of the Gibraltar arc, the Western Betics, which is characterized by the presence of the Ronda Peridotites, the largest sub-continental mantle body in the world. New structural and kinematic data are presented that document the coeval development of E-W dextral strike-slip corridors and $\mathrm{N}^{\circ} 0^{\circ}$ trending thrust faults. We propose that the northern part of the Gibraltar arc has been formed, mainly during the Lower Miocene, by the westward motion of the Alboran Domain, accommodated by simultaneous E-W trending lateral ramps and $\mathrm{N} 60^{\circ}$ frontal thrust. The E-W strike-slip deformation zones, acting as lateral ramps of the moving and extending hinterland, more likely correspond to an upper-plate expression of slab tearing at depth.

\section{2/ Geological setting}

\section{1/ Overview of the Betic-Rif arc}

Figure 1 presents a simplified tectonic map of the Betic-Rif system. A major tectonic contact, hereafter called the Internal-External Zone Boundary (IEZB; Platt et al., 2013) divides the tectonic system in two zones: $1 /$ the Internal Zone, also called the Alboran Domain (red, dark green, blue and grey in Fig.1), characterized by metamorphic rocks with variable metamorphic grades and ages; and 2/ the External Zone, composed of two main tectonic domain: the Subbetics (in Spain) / Intra- and Meso- Rif (in Morocco) that consist in a nonmetamorphosed Mesozoic and Tertiary sedimentary cover on top of the Iberian/Maghrebian basement (pale green in Fig.1) and the Flysch Trough Complex (Cretaceous to Miocene sediments, orange together with Miocene deposits of the Western Betics in Fig.1).

The Internal Zone, or Alboran Domain, is structurally made of a nappe pile of three tectonic units, which are, from bottom to top: the Nevado-Filabride, the Alpujarride and the Malaguide (see Didon et al., 1973; Egeler and Simon, 1969; Torres-Roldán, 1979).

The Nevado-Filabride is cropping out only in the central and eastern part of the Betics and is mainly composed of Paleozoic orthogneisses and graphitic schists with a thin PermoTriassic cover (light brown in Fig. 1, Bakker et al., 1989; García-Dueñas et al., 1988; Martínez-Martínez et al., 2010; Platt et al., 1984). Late Jurassic metamorphosed mafic (Hebeda et al., 1980; Puga et al., 2011) and ultramafic (Padrón-Navarta et al., 2008; Puga et al., 1999) rocks occur locally and are interpreted as Tethysian oceanic remnants affected by a 
Tertiary (Monié et al., 1991; Platt et al., 2006) high-pressure metamorphic event. Note that the Nevado-Filabride has no equivalent in the Rif.

The Alpujarride, Sebtide in the Rif, mainly consists of Paleozoic/Early Mesozoic crustal rocks (several tectonic units with different tectonic evolution, e.g. Booth-Rea et al., 2005) that contain large bodies of sub-continental peridotites (Ronda and Beni Bousera Peridotites, Obata, 1980). The Alpine metamorphic grade generally increases westward (Tubía et al., 1992), from high-pressure/low-temperature south of Granada (Goffé et al., 1989) to medium-pressure/high-temperature in the Western Betics (Platt and Whitehouse, 1999). The Alpujarride is characterized by a strong Oligo-Miocene extensional deformation (Balanyá et al., 1997; Argles et al., 1999; Précigout et al., 2013) and by a widespread Lower Miocene high-temperature metamorphic event (Monié et al., 1994). The age of an earlier high-pressure metamorphic event is debated: Paleozoic for Zeck and Whitehouse, 2002; Eocene for Platt et al., 2005; Oligocene for Monié et al., 1991; Lower Miocene for Tubía et al., 2013. The Mesozoic cover in the Alpujarride Unit is exclusively Triassic (e.g. MartinRojas et al., 2009, 2014).

The Malaguide (Ghomaride in the Rif; Durand-Delga, 1963, 1980) is composed of Paleozoic rocks with Hercynian low-grade metamorphism (Chalouan and Michard, 1990). Close to the Alpujarride, the Alpine metamorphic grade increases (Negro et al., 1996) with occurrence of andalusite (Cuevas et al., 2001; Platzman et al., 2000), partly suggesting a common evolution for Malaguide and Alpujarride during the regional Alpine metamorphism (Torres-Roldán, 1979). The non-metamorphic cover is Mesozoic to Paleogene (Chalouan et al., 2008; Martín-Algarra et al., 2009; Perri et al., 2013).

In the westernmost part of the Betic-Rif system, the Internal-External Zone Boundary (IEZB) is marked by the Dorsale units (Bourgois, 1978; Martín-Algarra et al., 2004a), which are composed of deformed and locally metamorphosed at high-grade Triassic-Jurassic sediments. The relationship between the Dorsale and the other units of the Alboran Domain is still debated: belonging to the Alpujarride, according to Chalouan et al. (2008) and Wildi et al. (1977), or belonging to the Malaguide, according to Didon et al. (1973), Balanyá and García-Dueñas (1987) and Sanz de Galdeano et al. (2001b).

The External Zone is characterized by a fold and thrust belt of Miocene age (Burdigalian-Langhian, Crespo-Blanc and Frizon de Lamotte, 2006) that affects two domains, called Subbetics and "Flysch Trough Complex". The Subbetics are the Mesozoic to Tertiary sedimentary cover partly detached from the Iberian margin basement, equivalent to Infra and 
Meso-Rif for the Maghrebian margin (see discussion in Crespo-Blanc and Frizon de Lamotte, 2006). The Subbetics are divided into several tectonic units (External Subbetics, Median Subbetics and Internal Subbetics), mainly based on their paleogeographic position during the Jurassic and the observed differences in sedimentary facies of the Cretaceous deposits (García-Hernandez et al., 1980; Vera et al., 2004, Martín-Algarra et al., 2004c).

Along the Gibraltar arc, deep marine clastic sediments, called hereafter the "Flysch Trough" (Martín-Algarra et al., 2004b; Luján et al., 2006; Stromberg et al., 1998; orange in Fig. 1) lies structurally on top of the Subbetics. The Flysch Trough that was deposited during the Lower Cretaceous (Thurow and Kuhnt, 1986) in a structural depression floored by oceanic or thinned continental crust, probably related to a transform setting (Biju-Duval et al., 1977; Dercourt et al., 1986), is mainly composed by Miocene (Guerrera et al., 2012) terrigenous sediments. The "Flysch Trough" is organized in a coherent accretionary prism north of Gibraltar (Luján et al., 2006) and is divided in two main groups: 1/ slivers of Cretaceous sediments at the base, considered as separated tectonic units (Martín-Algarra, 1987) and 2/ large amounts of Paleogene to Miocene flysch-type deposits, considered as pre-compression and Aquitanian to Lower Burdigalian in age (Martín-Algarra et al., 2004b). The sediments are usually separated in several units on the base of the relative abundance of quartz or lithic fraction (Aljibe quartzose, Algeciras only lithic and Bolonia a mix of both component, Martín-Algarra et al., 2004b, see Fig. 2 for a summary of different lithological units). Sedimentation ends in the Lower Miocene, marking the onset of the main shortening event in the Flysch Trough (Luján et al., 2006).

Lower Miocene-Quaternary foreland sediments delineate the northern and southern terminations of the Betic-Rif arcuate belt: the Guadalquivir Basin in the Betics and Rharb Basin in the Rif (Berástegui et al., 1998; Fernández et al., 1998; Flinch, 1993, white in Fig. 1). The transition between the Subbetics and the foreland sediments is an area of re-sedimented Mesozoic material embedded in evaporites and clays called "Guadalquivir allochthons" in the Betics (pale olive-green in Fig. 1; Platt et al., 2013; Ruiz-Constán et al. 2012a). It is characterized by a scarcity of outcrops that prevents good structural analysis (Sanz de Galdeano et al., 2008).

\section{2/ Geodynamical scenarios of the Alboran region}

Although the overall geometry of the Betic-Rif belt is relatively well defined (see Platt et al., 2013, Crespo-Blanc and Frizon de Lamotte, 2006; Chalouan et al., 2008 for review), its 
tectonic origin has been matter of debate in the past. Several geodynamical scenarios have been proposed to explain the arcuate geometry of the Alboran system and are reviewed here in their order of appearance.

Andrieux et al. (1971) postulated that an exotic microplate has indented the Iberian and Maghrebian margin. Strike-slip shearing along the lateral boundaries of the supposed exotic rigid indenter has been observed all along the Betics (De Smet, 1984; Sanz de Galdeano, 1990) and in the eastern and southern sectors of the Rif (Leblanc, 1990; Olivier, 1981). In particular, the major sinistral trans-Alboran shear zone (De Larouzière et al., 1988) is underlined by volcanism (grey in Fig. 1) and extends unambiguously for at least $400 \mathrm{~km}$ from the Eastern Betics (Bousquet, 1979; Pacquet, 1969; Rutter et al., 2012) to Morocco (Olivier and Leblanc, 1984) through the Alboran Sea (Booth-Rea et al. 2007). However, extension described in the Alboran Domain (Argles et al., 1999; Balanyá et al., 1997; GarcíaDueñas et al., 1992; Précigout et al., 2013) is not explained by this interpretation that must be therefore ruled out.

Platt and Vissers (1989) then formulated a first hypothesis that takes into account the existence of low-angle normal faults in the Alboran system, postulating a gravitational collapse of a previous mountain belt behind the formation of the Betic-Rif arc. This collapse should have induced a radial displacement around the Alboran Domain with contemporaneous compression in the foreland and extension in the hinterland. García-Dueñas et al. (1992) invoked a delamination of continental lithosphere to explain a similar deformation pattern in the Betic-Rif belt.

Nowadays, the most commonly accepted geodynamic scenario refers to the rollback of a subducting slab (Royden, 1993) to explain the arcuate evolution of the Betic-Rif External Zone and the extensional structures in the Alboran Domain (Royden, 1993; Lonergan and White, 1997). Furthermore, the spatial distribution of the different types of volcanism (Duggen et al., 2004), the shifting along the Betics of the marine-continental transition in onshore sedimentary basins (Iribarren et al., 2009), and the tectonic evolution of the Ronda Peridotites (Garrido et al., 2011; Précigout et al., 2013; Afiri et al., 2011; Johanesen et al., 2014) also suggest a subduction rollback origin for the mountain belt and its metamorphic units. However, the amount of slab rollback and the direction of trench migration is matter of controversy (see review in Chertova et al., 2014). A first category of interpretations considers an initial northwest-dipping subduction along the west-central Mediterranean (from Gibraltar or southeast of Iberia to Corsica) initiated in Oligocene and rolled back first to the south and then to the west (Faccenna et al., 2004; Jolivet et al., 2006; Guegen et al., 1998). In a second 
category, a short N-S trending subduction zone located south of the Baleares islands rolled back westward during the upper Miocene (Frizon de la Motte et al., 2009; Rosenbaum et al., 2004; Spakman and Wortel, 2004; Van Hinsbergen et al., 2014). Subduction of the Moroccan continental margin may trigger crustal delamination from the downgoing sub-continental mantle and could explain the peculiar kinematics of the Rif with respect to Iberia in presentday GPS data (Fadil et al., 2006; Pérouse et al., 2010). A third category considers an initial subduction zone dipping to the S-SE under the African margin (Alpine type) that rolled back first northward and progressively to the NW (Vergés and Fernández, 2012).

The direction and timing of the Alboran Domain displacement, that is the subduction upper-plate, is therefore a key issue to discriminate between different models. A tectonic study such as the one presented here cannot alone definitely rule out some of the proposed models. However, our study provides new geological and structural constraints, collected in key areas of the Western Betics that allow constraining the Lower Miocene displacement history of the Western Alboran Domain.

\section{3/ Lower Miocene extension and compression in the Western Betics}

The timing and direction of displacement in the Alboran Domain has been partly constrained by the deformation in its western part, mainly in the External Zone (Kirker and Platt, 1998; Balanyá et al. 2007) and Dorsale units, in the Western Betics (Mazzoli and Martín-Algarra, 2011) and in the Rif (Vitale et al. 2014a, 2014b). Figure 2 summarizes the Miocene tectonics of the Western Betics that is marked by the succession of compressive and extensional events (see Balanyá et al., 1997 and reply by Platt, 1997; Crespo-Blanc and Campos, 2001).

The Flysch Trough Complex is affected by an upper Burdigalian/Langhian shortening event giving an external fold and thrust belt (Luján et al., 2006) with coeval deposition of external lower Miocene olistostromic complex (e.g. Martín-Algarra et al., 2004b, Platt et al., 2013, Fig. 2 and see discussion in section 3.3). Consistently, Balanyá and García-Dueñas (1987) have proposed that the IEZB in the Western Betics (called by them "Gibraltar crustal thrust") formed during that main shortening event. In this paper, we will use the term Gibraltar thrust for the thrust-related portion of the IEZB that trends roughly $\mathrm{N}^{\circ} 0^{\circ}$ in the western Betics. The E-W portion of the IEZB will be denoted Torcal fault zone (Fig. 1).

Structural studies in the Western Betics have shown radial slip vectors in the External Zone that were interpreted as a result of either westward motion of the extending Alboran 
Domain (Balanyá et al., 2007) or radial motion of the Alboran Domain due to extensional collapse (Platt et al., 2003a). For Balanyá et al. (2007), the Alboran Domain motion would have been westward with a radial distribution of slip-vectors in the External Zone, from E-W north of Gibraltar to NW north of Ronda, as an effect of strain partioning from arc normal shortening to arc parallel extension (Balanyá et al., 2007; Fig. 3). In contrast, Kirker and Platt (1998) suggest a $\mathrm{N} 120^{\circ}$ unidirectional motion of the Alboran Domain in the Western Betics (Fig. 3b). The main difference between these two scenarios is the existence of a dextral transpressive E-W zone for Balanyá et al., 2007 (Torcal region; Balanyá et al., 2012) and N120 dextral strike-slip fault zone for Platt et al. (2003a) (see discussion in Balanyá et al. 2007; summarized in Fig. 3).

Such a motion of the Alboran Domain implies shortening at the front (mainly in the External Zone) and extension in the moving domain (Alboran Domain, Platt et al., 2013). In western Alboran, a major stage of extension occurred during Serravallian and is marked offshore by the large amount of subsidence in the Alboran basin (Comas et al., 1992) and onshore by extensional reactivation along the IEZB. Widespread low-angle normal faulting, mostly in the western part of the Alboran Domain, is considered to result from this major extensional event (García-Dueñas et al., 1992).

\section{4/ Extensional exhumation and thrusting of the Ronda Peridotites}

The largest onshore exposure worldwide of sub-continental mantle (Ronda and Beni Bousera), which is characterized by three typical metamorphic facies (Grt/Sp-peridotites, Granular Sp-peridotites, Pl-bearing peridotites; Obata, 1980), is a key geological feature of the Alboran Domain along the Gibraltar arc (Darot, 1973; Kornprobst, 1974; Obata, 1980).

These bodies of mantle rocks are characterized by: 1/ an extreme continental lithosphere thinning registered in both peridotites and surrounding crustal rocks and 2/ thrusting of the exhumed mantle into the Alboran Domain, allowing the final exhumation of peridotites at crustal depths (see review in Précigout et al., 2013). Sub-continental mantle exhumation was accommodated by extensional ductile shear in the upper part of the Ronda peridotitic bodies (in white in Fig. 4, Garrido et al., 2011; Précigout et al., 2013) and in the Alpujarride (Argles et al., 1999; Balanyá et al., 1997) and the Malaguide (Booth-Rea et al., 2003; Cuevas et al., 2001) in the Malaga area.

The regional foliation in the Alpujarrides crustal rocks is marked by mediumpressure/high-temperature assemblages that recorded a decrease in pressure (Argles et al., 
1999; Balanyá et al., 1997). Simultaneously, mantle rocks have registered a continuous decompression from garnet stability field to spinel-peridotite facies (Garrido et al., 2011), associated with ductile strain localization in the very top of the mantle section (Précigout et al., 2013). The occurrence of syn-tectonic partial melting (Marchesi et al., 2012) confirms the syn-exhumation mylonitization hypothesis. A similar tectonic evolution occurs in the Beni Bousera peridotites (Afiri et al., 2011; Frets et al., 2014). The complex polycyclic history that characterizes the mantle section, as suggested by occurrence of pseudomorphs after diamond (Davies et al., 1993) and by Hercynian, Jurassic and Alpine ages (Montel et al., 2000; Sánchez-Navas et al., 2014; Sánchez-Rodriguez and Gebauer, 2000), allows a certain degree of freedom for interpreting the age of continental lithosphere thinning.

The basal surface of the peridotites slices is a "hot" thrust (Esteban et al., 2008, Tubía et al., 1997), which will be called hereafter the Ronda Peridotites Thrust, observable in the Western Betics and very locally in the Rif (e.g. Ceuta). Partial melting in crustal rocks below the "hot thrust" yields a cluster of ages between $22 \mathrm{Ma}$ and $20 \mathrm{Ma}$ (Esteban et al., 2011), supporting a lower Miocene age for the "hot" thrusting.

Previous tectonic scenarios either do not consider the presence of mantle rocks (Andrieux et al., 1971) or proposed very different mechanisms and ages for mantle rock exhumation: i) mantle core complex (Doblas and Oyarzun, 1989), ii) extrusion of a mantle wedge during transpression along a subducting slab (Tubía et al., 1994; Mazzoli and MartínAlgarra, 2011), iii) successive detachment faults during extensional collapse of the Betic-Rif chain (Van der Wal and Vissers, 1993; Platt et al., 2003d) and iv) the inversion of a thinned back-arc lithosphere during slab rollback (Garrido et al., 2011 ; Précigout et al., 2013). Ages of exhumation are also strongly variable: i) Paleozoic (Kornprobst, 1976; Ruiz Cruz and Sanz de Galdeano, 2014), ii) Mesozoic (Tubía et al., 2009; Van Hinsbergen et al., 2014) and iii) Oligo-Miocene (Hidas et al., 2013; Précigout et al., 2013).

\section{5/ Objectives of the study}

The above review of previous studies regarding the Alboran region, and more specifically the Western Betics, shows that a major contractional event started during Lower Miocene in both the western External Zone (IEZB and fold-and-thrust belt in the Flysch Trough: Burdigalian/Langhian) and in the western Alboran Domain (Ronda Peridotites Thrust: Aquitanian). This lower Miocene shortening event occurs during the motion of the Alboran Domain, whose direction remains to be constrained (E-W or N120 , as shown in Fig. 
3). Our study is therefore focused on the relative development of the IEZB and the Ronda Peridotites Thrust during lower Miocene in relation with the motion of the Alboran Domain. It aims: at 1/ mapping at regional-scale the strike-slip deformation zones involved in the internal deformation pattern, $2 /$ constraining the timing of deformation, and $3 /$ providing rough estimates of regional-scale shortening.

Consequently, the pre-Miocene history, related to the subduction and exhumation of the Alpujarride and to the unroofing of the Ronda Peridotites, and the mid-Miocene to present-day history, related to Serravallian extension in the Alboran Basin with supposed extensional reactivations onshore and recent contractional events (Fig. 2), are beyond the scope of the present paper. Nevertheless, we later discuss in the paper the implications of our tectonic model to the Lower Miocene to present day evolution of the Western Betics.

\section{3/ Lower Miocene tectonics of the Western Alboran Domain}

\section{1/ Data acquisition}

The tectonic map shown in figure 4 presents the major tectonic features of the Western Alboran Domain and of the boundary with the External Zone. This map combines our own work (four months of fieldwork; around 8000 measurements) and previously published structural and geological data (IGME maps of Cano Medina, 1990; Cano Medina F. and Ruiz Reig (1990); Chamón Cobos et al., 1972; Cruz San Julían, 1990; Del Olmo Sanz et al., 1984, 1990; García de Domingo et al. 1994; Moreno Serrano et al., 1991; Piles Mateo et al., 1972a, 1972b; Pineda, 1983; and maps from Esteban et al., 2008; Sánchez-Gómez et al., 1999, 2002; Tubía et al., 1997; Sanz de Galdeano and Andreo, 1995). We identify four main areas (analyzed in sections 4 and 5) where contractional, extensional and strike-slip structures involving post-lower Burdigalian formations are unconformably covered by Late Tortonian Early Messinian Conglomerate (López-Garrido and Sanz de Galdeano, 1999; Martín et al., 2001; Figs. 4 and 5). Therefore, the deformation patterns that we infer started during lower Miocene. Other recent studies also suggest that strike-slip deformation zones were active in Pliocene times (Díaz-Azpiroz et al., 2014) implying that the inferred deformation kinematics has been active from Mid-Miocene to present day. The fact that these structures do not show any systematic cross-cutting relationships suggests their coeval development. Fault slip-data were collected mainly in the External Zone at the boundary with the Alboran Domain where the IEZB has an arcuate trend and around major E-W fault trending zones within the Alboran 
Domain.

Foliation trajectories and bedding envelopes outline the existence of large-scale faults and the deformation pattern of the Alboran Domain (Figs. 6 and 8). Local observations (fault geometries and kinematic indicators) and constraints deduced from geological and structural maps (lithostratigraphy and foliation trajectories) are used to identify and describe map-scale structures (as summarized in Fig. 4). Local observations and structural data analysis are reported in sections 4 and 5. The overall kinematics of the Western Betics during lower Miocene deformation are described and interpreted in section 6.

\section{2/ Tectonic units}

Figure 4 shows the two main tectonic contacts that characterize the Western Betics .1/ The IEZB (Platt et al., 2013) separates the External Zone from the overlying Alboran Domain and is delineated by Lower to Middle Miocene sediments that contain blocks of the overlying Alboran rocks ("Blocky-clays" deposits, Bourgois, 1978: External LMOC, little white dots on orange in Fig. 4). The age of these sediments are however not well established, between Burdigalian and Mid Miocene and formed by gravitational dismembering of the Alboran front (Suades and Crespo-Blanc, 2013). 2/ The Ronda Peridotites Thrust divides the Western Alboran Domain into two units. The Lower Western Alboran Unit is made of unmetamorphosed sediments (Dorsale) and metamorphic rocks ("Blanca"). The Upper Western Alboran Unit is a slice of thinned continental lithosphere (peridotites and crustal rocks). In the Western Betics, the IEZB is marked from West to East by the Gibraltar Thrust in the Gibraltar area (Balanyá and García-Dueñas, 1987) and the E-W Torcal fault zone (Martín-Algarra, 1987). As mentioned above, the Torcal fault zone has been described as either a $\mathrm{N} 120^{\circ}$ dextral strike-slip zone (Platt et al., 2003a) or a $\mathrm{N} 90^{\circ}$ strike-slip deformation zone (Balanyá et al., 2012). EW and NS cross-sections (Fig. 4) show the tectonic superposition of the Western Betics units and the major fault zone.

The Upper Western Alboran Unit corresponds to a strongly attenuated continental lithosphere section, whose thickness is as low as $5 \mathrm{~km}$ (cross-section in Figure 5 and GarcíaDueñas et al., 1992) showing from bottom to top: 1/ the Ronda Peridotites (sub-continental mantle, dark green; Fig. 4), 2/ the Alpujarrides crustal rocks (dark brown; Fig. 4), locally denoted Jubrique Unit (Balanyá et al., 1997) or Los Reales Nappe (including the Ronda 
Peridotites; Navarro-Vilá and Tubía, 1983) that corresponds to a deep- to mid-crust rock-pile as shown by the decrease in metamorphic grade from granulite to low grade schists, in which lithostratigraphic repetitions may occur (Balanyá et al., 1997) and 3/ the Malaguide (light brown; Fig. 4) that is made of upper crustal rocks, weakly or non metamorphosed (MartínAlgarra, 2004a).

The base of the Upper Western Alboran Unit is underlined by plagioclase-bearing peridotites (light green; Figs. 4 and 5) whose foliation developed in low-pressure conditions (Hidas et al., 2013), very well developed in the vicinity of the Ronda Peridotites Thrust and cross-cutting the previous garnet-spinel foliation (Précigout et al., 2013). This leads Hidas et al. (2013) to suggest that the plagioclase tectonites marked the thrusting related-deformation within the peridotites. Moreover, previous studies (Esteban et al., 2008; Mazzoli et al., 2011) have shown that the thrusting of the Ronda Peridotites and its crustal envelope on top of the Lower Western Alboran Unit occurred at low pressure and high temperature. The Ronda Peridotites Thrust is responsible for a dynamo-thermal contact metamorphism in the Lower Western Alboran Unit (i.e. "hot" thrusting) and to the intrusion of leucogranite dikes that cross-cut the Ronda Peridotites and its crustal envelope (Cuevas et al., 2006; Tubía et al., 1997). All the above considerations from the literature support our tectonic division of the Western Alboran Domain in two major units (Upper and Lower Western Alboran) separated by a major thrust. The clustering of leucogranite dike ages between 22 and 20 Ma (Esteban et al., 2011) shows that the Ronda Peridotites Thrust has a Lower Miocene age. Note that the subdivision in two units of the Alboran Domain is not relevant for Central and Eastern Betics where HP/LT units (e.g. Nevado-Filabride) with no equivalent in the Western Betics crop out below the Alpujarride (Platt et al., 2006) and where the Alpujarride does not contain mantle slivers.

The Lower Western Alboran Unit is composed mainly by "Blanca" rocks that consist mainly of a gneissic basement locally migmatitic (Acosta-Vigil et al., 2014; SánchezRodriguez, 1998) covered by Triassic marbles (Sanz de Galdeano and Andreo, 1995). Locally, tectonic slivers made of Triassic (dolomitic-) and Jurassic (cherty-) limestones (O’Dogherty et al., 2001), called Dorsale Units (Martín-Algarra et al., 2004a), underline the footwall of the Ronda Peridotites Thrust and the hanging-wall of the Gibraltar Thrust. At regional scale, these Dorsale Units underline the Gibraltar Thrust in both Betics and Rif (Expósito et al., 2012; Martín-Algarra, 1987; Olivier, 1984). Conglomerates, considered postLower Aquitanian (Felder, 1981), locally marked the Ronda Peridotites Thrust found on top 
of the Dorsale Units (Nava Breccia; dotted orange in Fig. 4) (Bourgois, 1978; Martín-Algarra and Estévez, 1984). Note that high-temperature metamorphism has been recently described in Dorsale Units located immediately below the peridotites (forsterite in dolomitic marble, Mazzoli et al., 2013). From the above metamorphic arguments, we propose that the "Blanca" rocks and the Dorsale Units correspond to the same tectonic unit (i.e. the Lower Western Alboran Unit), with variable degrees of high-temperature metamorphism and deformation resulting from the "hot" peridotites thrusting.

\section{3/ Lower-Mid Miocene Olistostromic Complex (LMOC)}

Chaotic deposits, interpreted as of Lower to Mid Miocene age (Fig. 2) (Martín-Algarra et al., 2004c), characterize the Western Betics: the "Blocky-clays" formation in the External Zone and the Neonumidian formation on the Alboran Domain rocks (Bourgois, 1978). For sake of simplicity, these two Lower to Mid Miocene Olistostromic Complexes (LMOC) are called hereafter, according to their present-day location, External LMOC deposit on the External Zone and the Internal LMOC on the Alboran Domain (Fig. 2 and dotted orange in Fig. 4). Since Miocene sedimentation in these two basins is very similar, the transition in the northern sector of the Western Betics between Internal LMOC and External LMOC is not easy to identify (Crespo-Blanc and Campos, 2001), suggesting that these two basins were most likely connected at that time (Bourgois, 1978; Martín-Algarra, 1987).

This olistotromic deposit composes the major part of the Alboran Domain cover and has been previously called Alozaina complex (e.g. Balanyá et al., 2007). However, the base of the transgressive cover of the Alboran Domain (Fig. 2) that crops out mainly near Alozaina and La Viñuela, (orange without dots; Fig. 4) is usually divided in two formations (see Fig. 2): Ciudad-Granada at the base and La Viñuela at the top (Serrano et al., 2007). The stratigraphic succession is characterized by a deepening trend upward with a change in sedimentation-type at around $20 \mathrm{Ma}$, corresponding to the temporal boundary between the two formations (Serrano et al., 2007). The sediments were deposited exclusively on the Malaguide in the Ciudad Granada formation. In the La Viñuela formation the deposition started at $20 \mathrm{Ma}$ involving metamorphic rocks of the Alboran Domain and locally peridotites (Aguado et al., 1990). The major part of the Alboran terrigenous sediments is composed of Lower to Mid-Miocene olistostrome-type deposits (LMOC), with blocks of Alboran Domain (Malaguide and Dorsale; Martín-Algarra, 1987) and of Flysch Trough Complex (Suades and Crespo-Blanc, 2013). 
The Western Alboran Domain shows at map scale three main types of structures: strike-slip faults (Sanz de Galdeano, 1990; Sanz de Galdeano et al., 2001a), thrust faults and related folds (Balanyá and García-Dueñas, 1987; Kirker and Platt, 1998) and normal faults (Crespo-Blanc and Campos, 2001; García-Dueñas et al., 1992; Platt et al., 2003b).

Several strike-slip faults have been identified in the Western Alboran Domain with various orientations and either sinistral or dextral offsets (Balanyá et al., 2007; Sanz de Galdeano and López-Garrido, 2012a, 2012b; Sanz de Galdeano et al., 1998; Sosson et al., 1998). A N140 ${ }^{\circ}$-trending sinistral fault is located to the NW of Estepona (Fig. 4) (Balanyá et al., 2007; Kirker and Platt, 1998; Sanz de Galdeano et al., 1999). E-W trending dextral faults are located in the Subbetics (Bourgois, 1978; Martín-Algarra, 1987) and at some places in the Alboran Domain (Sanz de Galdeano et al., 1996, 2001a; Tubía et al., 1997). These strike-slip faults were considered to be second order structures related to compression (Platt et al., 1995). Recently, a structural study (Díaz-Azpiroz et al., 2014) suggested that the deformation pattern associated to the Torcal fault zone was dominated by E-W dextral shearing between Upper Miocene and Present. The present-day seismicity is moreover consistent with such deformation kinematics (Balanyá et al., 2012; Ruiz-Constán et al., 2012b). In the following, we argue that such a deformation pattern was mostly acquired during Lower Miocene but has most probably been active since then, corresponding to a single, although complex, deformation event. Our structural mapping documents the geometry and kinematics of two main strike-slip corridors that are major regional-scale tectonic features in the study area. The term "strike-slip corridor" is here used to pick out elongated and broad deformation zones characterized by dominant along-strike displacements. The Torcal corridor corresponds to the northern boundary of the Alboran Domain that is in contact with the External Zone. The Coín corridor separates a northern domain dominated by Dorsale Units and Internal LMOC sediments from a southern domain dominated by Ronda Peridotites and the "Blanca" rocks, as displayed at map scale (Fig. 4) and highlighted in the N-S cross-section (Fig. 5). Structural evidence for dextral strike-slip shear in these corridors was previously described by Barcos et al. (2011, 2014), Sanz de Galdeano and López-Garrido (2012a, 2012b) and Díaz-Azpiroz et al. (2014) for the Torcal de Antequera corridor and by Tubía et al. (1997), Sanz de Galdeano et al. (2001a) for the Coín corridor.

The orientation of thrusts (mainly $\mathrm{N} 45^{\circ}-50^{\circ}$, with the exception of the Flysch Trough) 
and related folds in the External Zone is based on previously published geological maps and our own mapping (in the vicinity of the IEZB) (Fig. 4). Jurassic formations outcrop in the core of open antiforms that likely reflect the presence of blind thrusts in the External Zone (as drawn in cross-section; Fig. 5). In the Alboran Domain, the Ronda Peridotites Thrust is strongly deformed in the hanging-wall of the IEZB (Fig. 4 and cross-sections in Fig. 5), as shown by the tectonic windows in which the Lower Western Alboran Unit crops out (southwest of Coín).

Normal faulting is widespread in the Western Betics. A strong extensional reactivation, mostly during Serravallian (see section 2), has been proposed for the IEZB, leading some authors to draw the IEZB as an extensional contact (Balanyá et al., 1997; Crespo-Blanc and Campos, 2001; García-Dueñas et al., 1992). Although the Ronda Peridotites Thrust is indeed slightly reactivated in extension at some places (e.g. in the vicinity of Alozaina; Fig. 4), this major extensional reactivation of previous thrusts is nevertheless questioned by several studies (Kirker and Platt, 1998; Mazzoli and MartínAlgarra, 2011; Esteban et al., 2013). Our objective is here to constrain the structure related to thrusting and not to discuss later reactivations. From our structural work, the most common map-scale normal faults trend $\mathrm{N} 140^{\circ}$ (Balanyá et al., 2007) and crosscut all the lithological contacts in the Alboran Domain and in the Subbetics (Fig. 4). These normal faults controlled the deposition of Upper Miocene (Late Tortonian to Early Messinian; Martín et al., 2001) sediments, in elongated basins trending $\mathrm{N} 140^{\circ}$ to the North-West of Ronda (Jiménez-Bonilla et al., 2011; Ruiz-Constán et al. 2009) (Fig. 2) and in the Alboran Domain, near Álora (López-Garrido and Sanz de Galdeano, 1999; Martín et al., 2001) (Fig. 4).

\section{5/Cross-sections}

Our regional-scale cross-sections (Fig. 5), based on our own structural data and previously published cross-sections that considered available geophysical data (Balanyá et al., 1997; García-Dueñas et al., 1992; Mazzoli and Martín-Algarra, 2011), show the relationships in time and space between the two main thrusts (Ronda Peridotites Thrust on top and Gibraltar Thrust/IEZB below) and the strike-slip corridors.

Cross-section AA' that is N-S oriented shows the relationship between the thrusts and the strike-slip corridors of Torcal to the North and Coín to the South, which are deformation zones, few kilometer wide, marked by abrupt changes in lithology.

Between the two corridors, the Ronda Peridotites Thrust is involved in broad synclines 
and anticlines close to the major strike-slip faults but maintains an almost flat-lying attitude. The Internal LMOC sediments, only observed in the northern block (between the Torcal and Coín Corridors) are deposited and deformed in such a syncline.

Cross-section BB', that is E-W oriented, highlights the relationship between the Gibraltar Thrust (the N60'-trending segment of the IEZB) and the Ronda Peridotites Thrust that is folded in the hanging-wall of the Gibraltar Thrust. Moreover, the Upper Western Alboran Unit is dipping westward on top of the Ronda Peridotites Thrust in the westernmost part of the cross-section. This geometry suggests a thrust-propagating system with a hangingwall ramp lying on top of a footwall flat. Conversely, to the East, the relationship between Upper and Lower Western Alboran Units corresponds to hanging-wall flat lying on top of a footwall ramp. The Gibraltar Thrust with a similar geometry acted in the same thrustpropagating system, resulting in a typical pile of in-sequence thrust-sheets. The deformation is accommodated along a few-hundred meters thick metamorphic sole but imply local inversion of the litho-stratigraphy in the footwall and in the hanging-wall (Fig. 5).

\section{4/ The Torcal strike-slip corridor}

The IEZB is characterized by a regional-scale arcuate shape in the northern part of the map where it evolves from $\mathrm{N}^{\circ}$ (Gibraltar thrust) to E-W (Torcal fault zone) (Fig. 4). A more detailed structural map of the IEZB in the northern Western Betics summarizes our structural mapping (see foliation trajectories in Fig. 6a and stereoplot Fig. 6b).

The map displays (Fig. 6a): 1) the Subbetics Units: Triassic clays and evaporites (violet), Jurassic massive limestones (blue) and layered Cretaceous marly-limestones (green); 2) the Upper Western Alboran Unit: Malaguide rocks (brown), Jubrique rocks (red) and peridotites, often serpentinized (green); 3) the Lower Western Alboran Unit (Dorsale and "Blanca" rocks in blue) and 4) sedimentary basins: Internal LMOC (pale yellow with little white dots), External LMOC (pale yellow with big white dots) and Tortonian-Messinian conglomerates (beige). The IEZB is strongly arcuate and fault data were therefore collected in several areas that could be representative for both almost N-S and E-W trends observed. In this area, map-scale relationships between normal, thrust and dextral strike-slip faults suggest their at least partly simultaneous development. Field measurements were made, as far as possible, on fault-mirrors cross-cutting the main pre-existing lithological discontinuities, and only in sectors where at map scale the three different types of faults (normal, thrust and dextral strike-slip) could be observed with a geometrically compatible pattern. Faults with 
non-ambiguous slip indicators were mainly identified at the boundaries between layered Cretaceous carbonates (green) and massive Jurassic carbonates (pale blue) in the Subbetics and along the lithological contacts between Jubrique gneisses and Malaguide slates and between marbles and schists in the Alboran Domain.

Fault kinematic analysis was made using the methodology of Marrett and Allmendinger (1990). Using the FSA software of Célérier (2013), we extracted from each fault population the strike-slip, normal and thrust faults with dispersion of slip-vector orientation of maximum $40^{\circ}$ with reference to a hypothetical pure fault with the same attitude. We calculated the average incremental principal strain axes and, in order to better visualize the results and data dispersion, the contour of the principal strain axes has been also obtained with the FaultKin software of Marrett and Allmendinger (1990). Detailed strain analyses of the corridor are provided in the supplementary material (also for the Coín Corridor) and the related overall strain pattern is given in Figure $6 c$.

Structural data (foliation strike and dip, fault-slip, fold axes) are derived from our structural mapping (conducted at a 1:50000 scale) and from available data for the area East of Álora (Booth-Rea et al., 2003) and North of the Huertas y Montes village (Crespo-Blanc and Campos, 2001). Foliation trajectories and bedding envelopes were constructed using around 900 measurements of the main foliation in crustal and mantle rocks and bedding in Mesozoic and Miocene sediments.

\section{1/ Structures of the El Chorro sector}

The E-W corridor, along $30 \mathrm{~km}$, is marked in the Subbetics by ENE trending enéchelon anticlines affecting competent Jurassic limestones (Fig. 4). The Torcal and El Chorro anticlines are separated by an $8 \mathrm{~km}$ long depression, filled by thin and partly deformed olistostromic sediments (Fig. 6a). The IEZB limits the anticlines to the South and corresponds to the master fault of the Torcal corridor deformation zone, as evidenced by the steepening of bedding and foliation at its vicinity (right side of Fig. 7a). Sub-horizontal Tortonian sediments lie unconformably on top of upward bent older layers of the El Chorro area (left side of Figs. $6 a$ and $7 a)$ providing an important time constraint for the deformation along the Torcal corridor.

Three sets of faults, E-W dextral strike-slip, $\mathrm{N} 60^{\circ}$ thrust and $\mathrm{N} 140^{\circ}$ normal, are responsible for the morphology of the en échelon anticlines and are widespread in the 
corridor. E-W dextral strike-slip fault zones bound the Torcal de Antequera massif to the North and South. The El Chorro sector is composed by an overall ENE trending anticline, well developed in its eastern part, delimitated by $\mathrm{N} 140^{\circ}$ normal faults to the East and by a $\mathrm{N} 60^{\circ}$ transpressional fault zone to the South, in lateral continuity with the southern dextral strike-slip fault of the Torcal area (Fig. 6a). The cylindrical best fit of bedding and foliation surfaces measured in the El Chorro sector in stereographic projection (Fig. 6b; box in Fig. 6a) gives an ENE trending axis, marked in the field by a big-scale box fold in the eastern part of El Chorro sector. A NE-trending thrust and an E-W strike-slip fault are located in the core of the anticline (inside the box of Fig. 6a).

Outcrop-scale reverse faults in the El Chorro sector show a dispersion with a distribution in 3 families: $\mathrm{N} 50^{\circ}, \mathrm{N} 70^{\circ}$ and $\mathrm{N} 110^{\circ}$. Despite this variation, probably due to lithological heterogeneities, the related slip-vectors display a remarkably constant trend $\mathrm{N} 160^{\circ}$. This indicates that all these reverse faults are kinematically compatible with a $160^{\circ}$ direction of shortening, which is almost perpendicular to the IEZB in this region.

Strike-slip faults oriented E-W or WSW-ENE are sub-vertical. Small R-type shear planes (Fig. 7b) and calcite fibers in veins usually mark the slip direction on fault surfaces. In the El Chorro area, their average trend is $\mathrm{N} 80^{\circ}$ with a scattering of almost $50^{\circ}$ and a high dispersion in the plunge angle (stereoplot; Fig. 6b). The slip-vectors always plunge at lowangle dominantly eastward, suggesting a vertical movement of the Subbetics relative to the Alboran Domain. E-W right-slip vertical faults do not cut the open fold responsible for the arcuate outcrop pattern of the Flysch sediments west of Ardales, which marks the western end of the corridor, in the Huertas y Montes region.

Normal faults are often marked by pull-apart type veins, showing usually calcite step structures, or by wear grooves in the contact strain zones between massive Jurassic limestones and layered Cretaceous marly-limestones (Fig. 7c). Trend dispersion of these faults dipping at high or low angles is large but with maxima around N140 and E-W (Fig. 6b).

The absence of a systematic cross-cutting relationship between E-W dextral strikeslip, $\mathrm{N} 70^{\circ}$ thrust faults and $\mathrm{N} 140^{\circ}$ normal faults suggests a coeval development of these three sets of faults. This indicates principal directions of shortening and stretching trending $\mathrm{N} 160^{\circ}$ and $\mathrm{N} 70^{\circ}$, respectively. En-échelon folding in the Subbetics, underlined and bounded by E-W 
dextral strike-slip faults, suggests that the whole set of faults resulted from E-W strike-slip simple shear, with locally a possible but small component of pure shear due to rheological contrasts between different lithological formations.

\section{2/ Structures of El Burgo sector}

$\mathrm{NE}$ of El Burgo, the IEZB has an average N20 trend at map scale. However, the combination of $\mathrm{N} 50^{\circ}$ thrust segments, $\mathrm{N} 140^{\circ}$ normal and rare strike-slip fault segments locally accommodate the IEZB arcuate geometry. In the study sector, bedding envelopes and fold axial traces follow the Gibraltar Thrust/IEZB contour at map scale (Fig. 6a). The trend variation of the folds from the northern part, close to Ardales, to the southern part, close to El Burgo, is also illustrated in Figure 6b. The pole of the cylindrical best fit of bedding pole stereoplot swings by almost $45^{\circ}$, keeping a sub-horizontal plunge. Therefore, no significant vertical movement can be postulated from the bedding strike and dip data. Folds in the layered Cretaceous marly-limestones can vary from tight to open, mainly as a function of their distance from the Gibraltar Thrust. They correspond to fault-propagation folds (Fig. 7d) whose dominant asymmetry indicates a top-to-the- W-NW sense of shear, consistent with the ramp-flat structures observed in the field (Fig. 7e).

As in the El Chorro sector, normal faults have a variable trend with a mean at $\mathrm{N} 140^{\circ}$ (Fig. 6b). The associated slip vectors show roughly a N50 direction of stretching.

\section{3/ Strain and kinematics}

In El Chorro sector, $\mathrm{N}^{\circ} 0^{\circ}$ trending thrust, E-W dextral strike-slip and $\mathrm{N} 140^{\circ}$ trending normal faults are found to be synchronous. The whole set of data acquired in this region indeed shows a 3D strain tensor with principal strain axes $\lambda_{1}$ trending $N 45^{\circ}, \lambda_{2}$ steeply dipping to the $\mathrm{NW}$, and $\lambda_{3}$ trending $\mathrm{N} 135^{\circ}$, indicating a transpressional regime. Moreover, the strain derived from the entire set of measurements in the El Burgo sector shows a plunge increase of $\lambda_{1}$ and shifting of $\lambda_{3}$ slightly towards a $\mathrm{N} 100^{\circ}$ trend, suggesting a thrust component increase (see schema Fig. 6d). This deformation pattern implies a large-scale vertical zone of dextral strike-slip simple shear with principal directions of shortening and stretching trending $\mathrm{N} 135^{\circ}$ and $\mathrm{N} 45^{\circ}$, respectively. At regional-scale, this implies a $\mathrm{N} 90^{\circ}$ direction of displacement of the Alboran Domain with respect to Iberia. This westward 
motion is accommodated by a lateral strike-slip ramp to the north (Torcal corridor) and a frontal thrust ramp to the west (Gibraltar Thrust). This is responsible for the general change in dip direction of the IEZB from $\mathrm{N}^{\circ} 0^{\circ}$ to E-W. An increase of the amount of dextral shear along the corridor likely explains the evolution of fold axis trend from $\mathrm{N} 40^{\circ}$ to $\mathrm{N} 70^{\circ}$ from north of El Burgo to El Chorro. Furthermore, clockwise block rotations measured by paleomagnetism (Platzman and Lowrie, 1992; Villalaín et al., 1994) (see paleomagnetic declinations in Fig. 6a and 8a) are in agreement with such a deformation pattern with simple shear and rotations involving also the frontal thrust ramp of the system (Gibraltar Thrust of the El Burgo sector).

Internal deformation within the Alboran Domain is also consistent with this E-W dextral simple shear. East and south-east of Carratraca, the interconnection between a WSWENE thrust fault, that reactivated a previous extensional structure (Argles et al., 1999; Esteban et al., 2004), E-W dextral strike-slip fault and a N140 trending normal fault-zone supports this overall strain pattern. Moreover, the leucogranite dikes, associated with the Ronda Peridotites Thrust, are more abundant in the vicinity of the E-W serpentinite fault gouges, suggesting also an interplay between E-W strike-slip faulting and "hot" thrusting.

The overall geometry of the Internal LMOC is controlled at map scale (Figs. 4 and 6a) by a $\mathrm{N}^{\circ} 0^{\circ}$ trending syncline whose orientation is compatible with the inferred principal strain directions. Because the type of sedimentation is mainly olistostromic in this basin (Suades and Crespo-Blanc, 2013), we suggest that the LMOC was deposited during the deformation along the strike-slip corridors. The Internal LMOC can therefore be interpreted as a piggy-back basin deposited and deformed during the westward motion of the Alboran Domain and, in the other hand, the contemporaneous and connected External LMOC as chaotic mélange deposited at the front of the advancing nappe and involved in the deformation (wildflysch). Late Tortonian-Early Messinian sediments, controlled by $\mathrm{N} 140^{\circ}$ normal faults NW of Malaga (Fig. 4) generally seal the previous structures. The deformation pattern described therefore occurs in Lower to Mid Miocene in time (Fig. 6). Note that the Late Tortonian - Early Messinian sediments are locally deformed (north of the Torcal strike-slip corridor), suggesting a continuous deformation from Lower Miocene to Upper Miocene (Díaz-Azpiroz et al., 2014; Insua-Arévalo et al., 2012).

\section{5/ The Coín dextral strike-slip corridor}


The Coín strike-slip corridor is characterized by the map-scale predominance of E-W trending dextral strike-slip faults. With a general E-W trend along $50 \mathrm{~km}$, the corridor involves the whole Alboran Domain (Fig. 8a; same colour captions than in Fig. 6a). The IEZB and the Subbetics sediments mark the western tip of the dextral fault zone and the E-W trending coastline starting in Malaga (Fig. 4) is its eastern end.

The Coín high strain deformation zone is around $4 \mathrm{~km}$ wide and divides the Alboran Domain in two E-W elongated lower strain blocks, as exemplified in the N-S cross-section (Fig. 5). The northern block displays the largest domain of Lower to Mid Miocene olistostromic sediments (LMOC) whose deposition is syn-kinematic with the strike-slip corridors. The southern block displays the deeper parts of the Alboran Domain with a large exposure of the Ronda Peridotites, the Ronda Peridotites Thrust and the "Blanca" rocks of the Lower Western Alboran Unit. Fault data were collected with the same criteria than those of section 4, in areas along the E-W trending corridor where at map scale the relationships between normal, thrust and dextral strike-slip faults could suggest a coeval action.

\section{1/ Internal deformation of the Alboran Domain}

The Alboran Domain is characterized by three main sets of faults trending $\mathrm{N} 50^{\circ}, \mathrm{N} 90^{\circ}$ and $\mathrm{N} 140^{\circ}$ and a minor fourth set trending N-S (Fig. 8a). The major set is the E-W-trending dextral strike-slip faults. The map-scale E-W trending faults are more common in the eastern part of the map (Fig. 8a) and are progressively replaced towards the west by splay faults with different orientations and kinematics (Fig. 8d), suggesting a progressive decrease of displacement towards the west.

The eastern part of the Corridor shows that the Ronda Peridotites Thrust is cut by E-W dextral strike-slip faults with a minimum apparent offset of $9 \mathrm{~km}$ (East of Cartama; Fig. 8a)

In the Coín-Torrecilla sector, the E-W strike-slip faults occur usually with a few meters wide brecciated zones, surrounded by highly fractured rocks. Flower structures (Fig. 9a) and tightly asymmetrical folds in the Malaguide slates (Fig. 9b) mark the dextral shearing in the fault damage zones. Fault mirrors within fault core zones display often grooves, striaes and slickenlines with plough marks (Fig. 9c). At outcrop scale, the trend of pure dextral strike-slip faults is scattered around an average E-W trend indicating that they probably represent minor shear planes (e.g. P- and R-shear planes of the Riedel shear model) oblique to 
the major shear surface (Fig. 8b). Rotation of foliation trajectories (South of Alhaurín, Fig. 8a) also supports the existence of major map-scale dextral strike-slip fault zones (e.g. in the panoramic view of Fig. 9d). Similarly, in the Albornoque window close to Coín, a SW-NE trending antiform developed in the zone of dextral strike-slip faults step-over (Fig. 8a) and explains the dispersion in trend and dip angle of bedding and foliation measurements (Fig. 8b). The depocenter geometry of the Internal LMOC was controlled by a N70 syncline to the East of Tolox, providing a Lower Miocene age for the NW-SE shortening. Conversely, flat-lying Late Tortonian - Early Messinian conglomerates are found in the vicinity of the Cartama anticline and hence post-date the inferred deformation pattern.

N140 ${ }^{\circ}$-trending normal faults (Fig. 8b) with a short horizontal length were identified at outcrop-scale by offsets, deflections and sigmoidal shapes of foliations trajectories in the fault damage zones. In this sector (south-west of Torrecilla), the Ronda Peridotites Thrust is cut by an E-W strike-slip fault (3 km of horizontal offset, Fig. 8a), explaining the change in trend of the thrust faults from $\mathrm{N} 60^{\circ}$ to $\mathrm{N}-\mathrm{S}$ north of the strike-slip fault (Fig. 8b). Note that the E-W strike-slip corridor ends onto the Ronda Peridotites Thrust into a N140 ${ }^{\circ}$-trending normal fault to the North and N70 ${ }^{\circ}$ thrust fault to the south. This strongly suggests that the strike-slip and normal faults and the Ronda Peridotites thrust developed more likely simultaneously.

\section{2/ The IEZB near Atajate}

To the East and West of Atajate (Fig. 8a), the trend of the IEZB progressively evolves towards the south from NE-SW, to E-W and then to NNE-SSW again. Strain along the IEZB is thus partitioned in strike-slip (Fig. 9e), NE-SW-trending IEZB, and thrust, E-W-trending IEZB, segments. The E-W strike-slip fault zone does not cross-cut the External LMOC to the West of Atajate, but implies a clockwise rotation of the fold axes (Fig. 9f) in the Subbetics.

\section{3/ Strain and kinematics}

Along the Coín Corridor, like along the Torcal corridor, the different fault sets do not show any systematic cross-cutting relationship, suggesting a coeval development of thrust, strike-slip and normal faults. The dominance of E-W dextral strike-slip faults indicates a dextral simple shearing along the corridor, with a NW-SE direction of shortening and NE-SW direction of stretching. Moreover, the whole set of acquired fault data shows a pure strike-slip 
3D strain tensor in the Coín sectors (128 data). The E-W strike-slip system merges into the IEZB, steepened and with a strike-slip kinematics only close to Atajate where the trend is generally E-W. The kinematic analysis (Fig. 8c) shows a distribution of the principal strain directions similar to the Alboran Domain pattern. The same type of relationship between the Ronda Peridotites Thrust and the strike-slip corridor strongly suggests that the same kinematics (i.e. NW-SE shortening and NE-SW stretching) controlled the motion of the Ronda Peridotites Thrust.

The trend of folds in the Subbetics evolves from NNE to ENE, suggesting a westward motion of the southern block with respect to the northern block. The Coín corridor is thus a deformation zone located inside the westward moving Alboran Domain, with a southward increase of displacement.

The strike-slip fault offset decreases from East to West: around $9 \mathrm{~km}$ near Cartama, 3 $\mathrm{km}$ in Torrecilla (offset of the Ronda Peridotites Thrust) and merging then into IEZB (Fig. 8a).

\section{6/ Lower Miocene coeval thrusting and strike-slip faulting}

\section{1/ Westward motion of the tectonic units along the IEZB}

The more likely tectonic scenario that explains the Lower Miocene deformation pattern observed in the Western Betics is a continuous westward translation of the tectonic units composing the Alboran Domain, with reference to Iberia.

The motion of the Alboran Domain is accommodated by two main movement zones: a $\mathrm{N} 60^{\circ}$-trending frontal thrust ramp (i.e. the Gibraltar Thrust) and an E-W lateral (strike-slip) ramp (i.e. the Torcal corridor). The combination of these two ramps (Boyer and Elliott, 1982) explains the arcuate geometry of the IEZB observed at their intersection, with trends roughly around $\mathrm{N} 60^{\circ}$ to the West and E-W to the North. The N-S strain gradient across the Alboran Domain leads to strain localization along the Coín Corridor. Brittle deformation affected the whole Western Betics with coeval N140 ${ }^{\circ}$ normal, N60 ${ }^{\circ}$ thrust and E-W strike-slip faults that are all compatible with an E-W-trending strike-slip simple shear whose principal directions of shortening and stretching trend $\mathrm{N} 135^{\circ}$ and $\mathrm{N} 45^{\circ}$, respectively.

This interpretation is consistent with the conclusion drawn by Balanyá et al. (2007) concerning the $\mathrm{N} 90^{\circ}$-trending Torcal strike-slip corridor. In addition, we suggest a 
transpressional regime along this corridor, as recently proposed by Díaz-Azpiroz et al., (2014). In a westward motion, transpressional deformation may be related to boundary effects along the lateral ramp between the moving Alboran Domain and the External Zone. As a consequence, any $\mathrm{N} 120^{\circ}$ strike-slip corridor in the Torcal area (Platt et al., 2003a) must be ruled out.

The novelty of our work is to show that an E-W strike-slip corridor developed inside the Alboran Domain, with a simple shear deformation pattern, strongly supports a westward displacement of the whole Alboran Domain (Fig. 10). This dextral simple shear at regionalscale also explains clockwise rotation of tectonic units (Platzman and Lowrie, 1992; Platt et al., 1995). Radial slip vectors in the External Zone (Balanyá et al., 2007; Platt et al., 2013, Figs. 3 and 10) are not incompatible with such a westward motion (the dispersion in slipvectors due to thrust-sheets rotation is demonstrated geometrically in the appendix of Kirker and Platt, 1998).

Neither the bulk amount of shortening accommodated by the IEZB nor the amount of westward displacement along the corridors can be precisely estimated since i) no available reflection seismic line images the whole study area, ii) the tectonic units have not a constant thickness, and iii) deformation is accommodated in several splays at the tip of the strike-slip corridors with no reliable displacement markers on their two sides. However, an important outcome of our study is that the amount of strike-slip displacement decreases westward. In the Torcal corridor, the evolution of fold axis trend from $\mathrm{N} 70^{\circ}$ to $\mathrm{N} 40^{\circ}$ along the lateral strikeslip ramp of the IEZB suggests a westward decrease of dextral displacement. Likewise, the measured horizontal offset in the Coín Corridor decreases westward from $9 \mathrm{~km}$ to $3 \mathrm{~km}$.

\section{2/ Relationship between Ronda Peridotites Thrust and IEZB, and ages of deformation}

On the basis of the new collected structural data (maps Figs. 6 and 8 and crosssections Fig. 5), we propose that the piling up of thrust units in the Western Betics occurred in two time steps. First, the Ronda Peridotites Thrust brought a portion of thinned continental lithosphere (Upper Western Alboran Unit, Précigout et al., 2013) on top of the Lower Alboran. This "hot thrusting" (i.e. bringing the hot base of a lithosphere section on top of upper crustal rocks) leads to i) high-temperature metamorphism of the footwall units, up to partial melting, and intrusion of acid dikes (Cuevas et al., 2006; Tubía et al., 1997) in the Upper Western Alboran Unit and ii) peridotite deformation in the plagioclase facies (Hidas et al., 2013; 
Précigout et al., 2013) and iii/ mafic dikes intrusion in the Ronda Peridotites with a geochemical signature indicating incipient subduction of Blanca-type rocks under the peridotites (Marchesi et al., 2012). During a second stage, more likely during the Lower to Mid Miocene (compare to Fig. 2), the IEZB lead to the emplacement of the previous nappe stack of the Alboran Domain onto the External Zone. However, the connection between the Ronda Peridotites Thrust and the IEZB (Gibraltar thrust) close to Atajate (Fig 4) may suggest a partly coeval activity of these two thrusts.

Our structural work supports that the second thrust-stage corresponds to a westward motion of the Alboran Domain accommodated by lateral (strike-slip) and frontal (thrust) ramps. Similarly, the arcuate geometry and the trend of the Ronda Peridotites Thrust close to the Coín Corridor also suggest a westward motion during the first stage of deformation. This interpretation is furthermore consistent with the deformation observed in the Dorsale Units (Mazzoli et al., 2011). Note that deformation patterns in the Lower Western Alboran Unit and at the base of the Ronda Peridotites indicate senses of shear top to NNW, NW or SW (Esteban et al., 2008; Mazzoli et al., 2011; Hidas et al., 2013), consistent with our analysis, but also top to ENE (Tubía et al., 1997). These local complexities can partly be related to a change in emplacement direction of the Upper Western Alboran Unit between 22 and 20 Ma.

On the above bases, we propose that the westward displacement of the Alboran Domain most probably started with the thrust emplacement of the Ronda Peridotites on top of the Lower Western Alboran Unit, at 22-20 Ma. Upper Miocene to Pliocene deformation, with similar kinematics, is moreover supported by field data (Díaz-Azpiroz et al., 2014), suggesting a continuous deformation along the E-W strike-slip corridors, from Lower Miocene to present day. Present-day seismicity (Ruiz-Constán et al., 2012b) and GPS displacement pattern (Koulali et al., 2011) are consistent with such a westward motion, accommodated by coeval strike-slip, thrust and normal faulting. The present-day GPS displacement of 2-3 mm/year (Koulali et al., 2011) would yield to an average displacement of 40-60 km during the past 20 Ma. Although the present-day displacement is not necessarily relevant for the past, it is worth noting that the length of the Internal LMOC that underlines the displacement along the Torcal corridor between La Viñuela and Alozaina is close to 60 km (Fig. 4).

\section{3/ Restored Miocene evolution of Western Alboran Domain}

We propose a reconstruction of the Alboran Domain during Miocene times involving a 
component of E-W dextral simple shear at regional scale (Fig. 10). The progressive westward migration of the active front, from the Ronda Peridotites Thrust (lowermost Miocene), to the IEZB (lower Miocene) and to the External Zone thrusts (mid- to upper Miocene) is partly accommodated by strain localization along E-W strike-slip corridors. The E-W orientation of the strike-slip corridors implies a westward movement of the whole thrusting domain. The former region of shortening is thus reactivated in extension, as suggested for the Alboran Domain during Serravallian time (García-Dueñas et al., 1992). The coeval development of EW strike-slip faults, $\mathrm{N} 60^{\circ}$ thrusts and $\mathrm{N} 140^{\circ}$ normal faults is moreover compatible with a NESW convergence between Africa and Europe during Miocene times (Mazzoli and Helman; Fig. 10). A change in direction of plate convergence from N-S to NE-SW (Vissers and Meijers 2012) could likely explain the onset of the westward motion of the Alboran Domain, accommodated by dextral strike-slip corridors at the boundary with the Iberia margin.

At lithosphere scale, the lateral ramp (Torcal Corridor) corresponds to the northern limit of deep mantle seismicity clusters observed in the Betics and in the Alboran Sea (Buforn et al., 2004; Calvert et al., 2000). Recent tomographic images confirm that the E-W trending northern limit of the Alboran Domain is the edge of a subduction system (Bonnin et al., 2014; Thurner et al., 2014). The lateral slab tearing that is imaged by tomographic models accommodated slab rollback at upper mantle depths. It might be thereby accompanied at crustal levels by the localization of westward displacement within the strike-slip corridors of Torcal and Coín (Fig. 10). The trenchward decrease of the amount of strike-slip displacement in the corridors strongly sustains this interpretation. Our structural and kinematic analysis can thus provide a geological description of the deformation pattern associated to slab tearing, over a $80 \mathrm{~km}$ distance. Slab tearing may have initiated during Lower Miocene and progressively lead to a complete lateral slab detachment, from East to West during Upper Miocene, triggering partly the Messinian salinity crisis (Duggen et al., 2003; GarcíaCastellanos et al., 2011).

\section{7/ Conclusions}

The major results of our study can be summarized as follows:

1/ Lower Miocene tectonics of the Western Betics resulted from a westward motion of the Alboran Domain, with respect to Iberia, accommodated by a lateral E-W dextral strike-slip 
ramp (Torcal corridor) and a frontal $\mathrm{N}^{\circ} 0^{\circ}$ thrust ramp (Gibraltar Thrust). The connection between these two major tectonic boundaries explains the arcuate geometry of the InternalExternal Zone Boundary (IEZB).

2/ Strain localization during dextral simple shear of the Alboran Domain gave birth to the EW Coín strike-slip corridor.

3/ The westward motion of the Alboran Domain led to a classical piling up of thrust units through the following thrust sequence: 1) the Ronda Peridotites Thrust, 2) the IEZB system and 3) external thrusts within the Subbetics. The crustal emplacement of large bodies of subcontinental mantle may therefore have occurred at the onset of this westward thrusting

4/ The onset of the westward motion of the Alboran Domain is constrained by the synkinematic deposition of the Lower to Mid Miocene (Burdigalian-Langhian) Olistostromic Complex (LMOC), in both the Internal and External Zones, and by the age of leucogranite dikes related to the Ronda Peridotites Thrust at around 22-20 Ma.

5/ A continuous westward motion of the Alboran Domain and hence of the active front is then recorded from 22-20 Ma to present day, more likely related to a continuous slab tearing at the northern edge of the Alboran domain. The E-W strike-slip corridors described in this study may be the crustal signature of slab tearing that accommodates the westward trench retreat at upper mantle depths.

\section{ACKNOWLEDGEMENTS}

This work was funded by the European Union FP7 Marie Curie ITN “TOPOMOD”, contract 264517. Alexandre Pichat and Hugo Humbert are acknowledged for the help during fieldwork. Thanks to Anne Delplanque for help in drawing Figure 4 and 5 and to Bernard Célérier for useful discussions. Very constructive comments made by an anonymous reviewer and Guillermo Booth Rea, as well as the professional handling of the Editor, helped to improve the manuscript.

\section{REFERENCES:}


Acosta-Vigil, A., Rubatto, D., Bartoli, O., Cesare, B., Meli, S., Pedrera, A., Azor, A., and Tajcmanova, L. (2014). Age of anatexis in the crustal footwall of the Ronda Peridotites, S. Spain. Lithos.

Afiri, A., Gueydan, F., Pitra, P., Essai, A., and Précigout, J. (2011). Oligo-miocene exhumation of the Beni-Bousera peridotite through a lithosphere-scale extensional shear zone. Geodinamica Acta, 24(1):49-60.

Aguado, R., Feinberg, H., Durand-Delga, M., Martín-Algarra, A., Esteras, M., and Didon, J. (1990). Nuevos datos sobre la edad de las formaciones miocenas transgresivas sobre las Zonas Internas Béticas : la Formación de San Pedro de Alcantara (Provincia de Málaga). Revista de la Sociedad Geológica de España, 3(1-2):79-85.

Andrieux, J., Fontboté, J., and Mattauer, M. (1971). Sur un modèle explicatif de l'arc de Gibraltar. Earth and Planetary Science Letters, 12:191-198.

Argles, T., Platt, J., and Waters, D. (1999). Attenuation and excision of a crustal section during extensional exhumation: the Carratraca massif, Betic Cordillera, southern Spain. Journal of the Geological Society, 156(1):149-162.

Bakker, H., Jong, K., Helmers, H., and Biermann, C. (1989). The geodynamic evolution of the Internal Zone of the Betic Cordilleras (south-east Spain): a model based on structural analysis and geothermobarometry. Journal of Metamorphic Geology, 7(3):359-381.

Balanyá, J. C., Crespo-Blanc, A., Díaz-Azpiroz, M., Exposito, I., Torcal, F., Perez-Peña, V., and Booth-Rea, G. (2012). Arc-parallel vs. back-arc extension in the western Gibraltar arc: is the Gibraltar forearc still active? Geol. Acta, 10:249-263.

Balanyá, J. C., Crespo-Blanc, A., Díaz-Azpiroz, M., Expósito, I., and Luján, M. (2007). Structural trend line pattern and strain partitioning around the Gibraltar arc accretionary wedge: Insights as to the mode of orogenic arc building. Tectonics, 26(2):TC2005.

Balanyá, J. C. and García-Dueñas, V. (1987). Les directions structurales dans le domaine d'alborán de part et d'autre du détroit de Gibraltar. Comptes rendus de l'Académie des 
sciences. Série 2, Mécanique, Physique, Chimie, Sciences de l'Univers, Sciences de la Terre, 304(15):929-932.

Balanyá, J. C., García-Dueñas, V., Azañón, J. M., and Sánchez-Gómez, M. (1997). Alternating contractional and extensional events in the Alpujarride nappes of the Alboran Domain (Betics, Gibraltar arc). Tectonics, 16(2):226-238.

Barcos, L., Díaz-Azpiroz, M., Balanyá, J., and Expósito, I. (2011). Dominios estructurales y reparto de la deformación en zonas transpresivas de corteza superior (Torcal de Antequera, Cadena Bética). Geogaceta, 50:31-34.

Barcos, L., Jiménez-Bonilla, A., Expósito, I., Balanyá, J. C. and Díaz-Azpiroz, M. (2014) Reparto de la deformación en la terminación oriental de la Zona de Cizalla del Torcal (Béticas, S España). Geogaceta, 56:23-26.

Berástegui, X., Banks, C., Puig, C., Taberner, C., Waltham, D., and Fernández, M. (1998). Lateral diapiric emplacement of Triassic evaporites at the southern margin of the Guadalquivir Basin, Spain. Geological Society, London, Special Publications, 134(1):49-68.

Bezada, M., Humphreys, E., Toomey, D., Harna, M., Dávila, J., and Gallart, J. (2013). Evidence for slab rollback in westernmost Mediterranean from improved upper mantle imaging. Earth and Planetary Science Letters, 368:51-60.

Biju-Duval, B., Dercourt, J., and Le Pichon, X. (1977). From the Tethys ocean to the Mediterranean seas: a plate tectonic model of the evolution of the western alpine system. Histoire structurale des bassins méditerranéens, pages 143.

Blanco, M. and Spackman, W. (1993). The P-wave velocity structure of the mantle below the iberian peninsula: Evidence for a subducted lithosphere below southern Spain. Tectonophysics, 221 (1):13-34.

Bonnin, M., Nolet, G., Villaseñor, A., Gallart, J., and Thomas, C. (2014). Multiple-frequency tomography of the upper mantle beneath the african/iberian collision zone. Geophysical Journal International, 198(3):1458-1473. 
Booth-Rea, G., Azañón, J. M., García-Dueñas, V., Augier, R., and Sánchez-Gómez, M. (2003). A «core-complex-like structure » formed by superimposed extension, folding and high-angle normal faulting. The Santi Petri dome (Western Betics, Spain). Comptes Rendus Geoscience, 335(2):265-274.

Booth-Rea, G., Azañon, J.M., Martinez-Martinez, J.M., Vidal, O. and Garcia-Dueñas, V. (2005). Contrasting structural and P-T evolution of tectonic units in the southeastern Betics: Key for understanding the exhumation of the Alboran Domain HP/LT crustal rocks (western Mediterranean). Tectonics, 24:TC2009.

Booth-Rea, G., Ranero, C.R., Martinez-Martinez, J.M., Grevemeyer, I. (2007). Crustal types and Tertiary tectonic evolution of the Alborán sea, western Mediterranean. Geochemistry, Geophysics, Geosystems, 8(10):Q10005.

Bourgois, J. (1978). La transversale de Ronda (Cordillères Bétiques, Espagne). Données géologiques pour un modèle d'évolution de l'Arc de Gibraltar. Annales Scientifiques de l’Université de Besançon (France), 30:1-445.

Bousquet, J.-C. (1979). Quaternary strike-slip faults in southeastern Spain. Tectonophysics, 52(1-4):277-286.

Boyer, S. E. and Elliott, D. (1982). Thrust systems. AAPG Bulletin, 66(9):1196-1230.

Brun, J.-P. and Sokoutis, D. (2010). 45 m.y. of aegean crust and mantle flow driven by trench retreat. Geology, 38(9):815-818.

Buforn, E., Bezzeghoud, M., Udías, A., and Pro, C. (2004). Seismic Sources on the IberiaAfrican Plate Boundary and their Tectonic Implications. Pure appl. geophys., 161(3):623-646.

Calvert, A., Sandvol, E., Seber, D., Barazangi, M., Roecker, S. Mourabit, T., Vidal, F., Alguacil, G., and Jabour, N. (2000) Geodynamic evolution of the lithosphere and upper mantle beneath the Alboran region of the western Mediterranean: Constraints from travel time tomography. J. Geophys. Res., 105(10):871-898. 
Cano Medina, F. (1990). Sheet Olvera, 1036. Geological map scale 1:50000, Instituto Geológico y Minero de España, Madrid.

Cano Medina, F. and Ruiz Reig, P. (1990). Sheet Ardales, 1051. Geological map scale 1:50000, Instituto Geológico y Minero de España, Madrid.

Célérier, B. (2013). FSA: Fault \& Stress Analysis software, version 35.1, http://www.pagesperso-bernard-celerier.univ-montp2.fr/software/dcmt/fsa/fsa.html.

Chalouan, A. and Michard, A. (1990). The Ghomarides nappes, Rif coastal range, Morocco: A variscan chip in the alpine belt. Tectonics, 9(6):1565-1583.

Chalouan, A., Michard, A., El Kadiri, K., Frizon de Lamotte, D., Negro, F., Soto, J., and Saddiqi, O. (2008). The Rif belt. In Continental evolution: the geology of Morocco, pages 203-302. Springer.

Chamón Cobos, C., Quinquer Agut, R., Crespo, V., Aguilar, M., and Reyes, J.L. (1972). Sheet Alora, 1052. Geological map scale 1:50000, Instituto Geológico y Minero de España, Madrid.

Chertova, M. V., Spakman, W., Geenen, T., Van den Berg, A. P., and Van Hinsbergen, D. J. J. (2014). Underpinning tectonic reconstructions of the western Mediterranean region with dynamic slab evolution from 3-D numerical modeling. J. Geophys. Res., Solid Earth, 119:5876-5902.

Comas, M. C., García-Dueñas, V., and Jurado, M. (1992). Neogene tectonic evolution of the Alboran Sea from MCS data. Geo-Marine Letters, 12(2-3):157-164.

Crespo-Blanc, A. and Campos, J. (2001). Structure and kinematics of the south iberian paleomargin and its relationship with the Flysch Trough Units: extensional tectonics within the Gibraltar arc fold-and-thrust belt (Western Betics). Journal of Structural Geology, 23(10):1615-1630. 
Crespo-Blanc, A. and Frizon de Lamotte, D. (2006). Structural evolution of the external zones derived from the Flysch Trough and the south iberian and maghrebian paleomargins around the Gibraltar arc: a comparative study. Bulletin de la Societé Géologique de France, 177(5):267-282.

Cruz San Julían, J. (1990). Sheet Teba, 1037. Geological map scale 1:50000, Instituto Geológico y Minero de España, Madrid.

Cuevas, J., Esteban, J., and Tubía, J. (2006). Tectonic implications of the granite dike swarm in the Ronda Peridotites (Betic Cordilleras, southern Spain). Journal of the Geological Society, 163(4):631-640.

Cuevas, J., Navarro-Vilá, F., and Tubía, J. (2001). Evolución estructural poliorogénica del complejo Maláguide (Cordilleras béticas). Boletín Geológico y Minero, 112(3):47-58.

Dahlstrom, C. (1969). Balanced cross sections. Canadian Journal of Earth Sciences, 6(4):743757.

Davies, G. R., Nixon, P. H., Pearson, D. G., and Obata, M. (1993). Tectonic implications of graphitized diamonds from the ronda, peridotite massif, southern Spain. Geology, 21(5):471474.

Del Olmo Sanz, A., Macía de Pablo, J.G., Aldaya Valverde, F., Campos Fernández, J., Chacón Montero, J., García Rosell, V., Sanz de Galdeano, C., Orozco Fernández, M., TorresRoldán, R. (1984). Sheet Cortes de la Frontera, 1064. Geological map scale 1:50000, Instituto Geológico y Minero de España, Madrid.

Del Olmo Sanz, A., Moreno Serrano, F., Campos Fernández, J., Estévez, A., García-Dueñas, V., García-Rossell, L., Martín-Algarra, A., Orozco Fernández, M., and Sanz de Galdeano, C. (1990). Sheet Ronda, 1051. Geological map scale 1:50000, Instituto Geológico y Minero de España, Madrid.

Dercourt, J., Zonenshain, L. P., Ricou, L. E., Karmin, V. C., Le Pichon, X., Knipper, A. L., Grandjacquet, C., Sburtshickov, I. M., Geyssant, J., Lepvrier, C., Pechersky, D. A., Boulin, J., 
Sibuet, J. C., Savostin, L. A., Sorokhtin, O., Westphal, M., Bazhenov, M. L., Laver, J. P., and Biju-Duval, B. (1986). Geological evolution of the Tethys belt from the Atlantic to the Pamir since the Lias. Tectonophysics, 123(1-4):241-315.

Dewey, J. F., Helman, M. L., Turco, E., Hutton, D. H. W., and Knot, S. D. (1989). Kinematics of the western Mediterranean. In Coward, M. P., Dietrich, D., and Park, R. G., editors, Conference on Alpine tectonics, Volume 45 of Geol. Soc. Lond. Spec. Pubs., pages 265-283. Geological Society of London, London.

Díaz-Azpiroz, M., Barcos, L., Balanyá, J. C., Fernández, C., Expósito, I., and Czeck, D. (2014). Applying a general triclinic transpression model to highly partitioned brittle-ductile shear zones: A case study from the Torcal de Antequera massif, external Betics, southern Spain. Journal of Structural Geology, 68, (B):316-336.

Didon, J., Durand-Delga, M., and Kornprobst, J. (1973). Homologies géologiques entre les deux rives du détroit de Gibraltar. Bulletin de la Societé Géologique de France, 15(2):77-105.

Doblas, M. and Oyarzun, R. (1989). Neogene extensional collapse in the Western Mediterranean (Betic-Rif alpine orogenic belt): Implications for the genesis of the Gibraltar arc and magmatic activity. Geology, 17(5):430-433.

Docherty, C. and Banda, E. (1995). Evidence for the eastward migration of the Alboran Sea based on regional subsidence analysis: A case for basin formation by delamination of the subcrustal lithosphere. Tectonics, 14 (4):804-818.

Duggen, S., Hoernle, K., van den Bogaard, P., Rupke, L., and Phipps Morgan, J. (2003). Deep roots of the Messinian salinity crisis. Nature, 422:602-606.

Duggen, S., Hoernle, K., van den Bogaard, P., and Harris, C. (2004). Magmatic evolution of the Alboran region: The role of subduction in forming the Western Mediterranean and causing the messinian salinity crisis. Earth and Planetary Science Letters, 218(1-2):91-108.

Durand-Delga, M. (1963). Essai sur la structure des domaines émergés autour de la méditerranée occidentale. Geol. Rundschau, 53:534-535. 
Durand-Delga, M. (1980). La Méditerranée Occidentale: étapes de sa genèse et problème structuraux liés à celle-ci. Mémoire hors série de la Société Géologique de France, 10:203224.

Egeler, C. and Simon, O. (1969). Orogenic evolution of the Betic zone (Betic Cordilleras, Spain), with emphasis on the nappe structures. Geologie en Mijnbouw, 48(3):296-305.

Esteban, J. J., Cuevas, J., Tubía, J., Sergeev, S., and Larionov, A. (2011). A revised Aquitanian age for the emplacement of the Ronda Peridotites (Betic Cordilleras, southern Spain). Geological Magazine, 148(01):183-187.

Esteban, J. J., Cuevas, J., Vegas, N., and Tubía, J. M. (2008). Deformation and kinematics in a melt-bearing shear zone from the Western Betic Cordilleras (southern Spain). Journal of Structural Geology, 30(3):380-393.

Esteban, J. J., Sánchez-Rodríguez, L., Seward, D., Cuevas, J., and Tubía, J. M. (2004). The late thermal history of the Ronda area, southern Spain. Tectonophysics, 389(1-2):81-92.

Esteban, J. J., Tubía, J. M., Cuevas, J., Seward, D., Larionov, A., Sergeev, S., and NavarroVilá, F. (2013). Insights into extensional events in the Betic Cordilleras, southern Spain: New fission-track and U-Pb SHRIMP analyses. Tectonophysics, 603:179-188.

Expósito, I., Balanyá, J. C., Crespo-Blanc, A., Díaz-Azpiroz, M., and Lujan, M. (2012). Overthrust shear folding and contrasting deformation styles in a multiple decollement setting, Gibraltar arc external wedge. Tectonophysics, 576-577:86-98.

Faccenna, C., Piromallo, C., Crespo-Blanc, A., Jolivet, L., and Rossetti, F. (2004). Lateral slab deformation and the origin of the arcs of the western Mediterranean. Tectonics, 23: TC1012.

Fadil, A., Vernant, P., McClusky, S., Reilinger, R., Gomez, F., Ben Sari, D., Mourabit, T., Feigl, K., and Barazangi, M. (2006). Active tectonics of the western mediterranean: Geodetic evidence for rollback of a delaminated subcontinental lithospheric slab beneath the Rif 
mountains, morocco. Geology, 34(7):529-532.

Fernández, M., Berástegui, X., Puig, C., García-Castellanos, D., Jurado, M. J., Torné, M., and Banks, C. (1998). Geophysical and geological constraints on the evolution of the Guadalquivir foreland basin, Spain. Geological Society, London, Special Publications, 134(1):29-48.

Flinch J.F. (1993). Tectonic evolution of the Gibraltar Arc. PhD thesis, Rice University, Houston, Texas.

Frets, E. C., Tommasi, A., Garrido, C. J., Vauchez, A., Mainprice, D., Targuisti, K., and Amri, I. (2014). The Beni-Bousera peridotite (Rif belt, Morocco): an oblique-slip low-angle shear zone thinning the subcontinental mantle lithosphere. Journal of Petrology, 55(2):283313.

Frizon de Lamotte, D. F., Leturmy, P., Missenard, Y., Khomsi, S., Ruiz, G., Saddiqi, O., Guillocheau, F., and Michard, A. (2009). Mesozoic and cenozoic vertical movements in the atlas system (algeria, morocco, tunisia): An overview. Tectonophysics, 475(1):9 - 28.

García-Castellanos, D. and Villaseñor, A. (2011). Messinian salinity crisis regulated by competing tectonics and erosion at the Gibraltar arc. Nature, 480: 359-363.

García de Domingo, A., Hernaiz Huerta, P., Balanyá, J. C., and García-Dueñas, V. (1994). Sheet Algeciras, 87. Geological map scale 1:200000, Instituto Geológico y Minero de España, Madrid.

García-Dueñas, V., Balanyá, J. C., and Martínez-Martínez, J. (1992). Miocene extensional detachments in the outcropping basement of the northern Alboran basin (Betics) and their tectonic implications. Geo-Marine Letters, 12:88-95.

García-Dueñas, V., Martínez-Martínez, J., Orozco, M., and Soto, J. (1988). Plis-nappes, cisillements syn- à post-métamorphiques et cisaillements ductiles-fragiles en distension dans les Nevado-Filabrides (Cordillères Bétiques, Espagne). Comptes Rendus de l'Académie des Sciences, Série 2, Mécanique, Physique, Chimie, Sciences de l'Univers, Sciences de la Terre, 
Garrido, C. J., Gueydan, F., Booth-Rea, G., Précigout, J., Hidas, K., Padrón-Navarta, J. A., and Marchesi, C. (2011). Garnet lherzolite and garnet-spinel mylonite in the Ronda peridotite: Vestiges of Oligocene backarc mantle lithospheric extension in the Western Mediterranean. Geology, 39(10):927-930.

Goffé, B., Michard, A., García-Dueñas, V., Gonzalez-Lodeiro, F., Monié, P., Campos, J., Galindo-Zaldívar, J., Jabaloy, A., Martínez-Martínez, J. M., and Simancas, J. F. (1989). First evidence of high-pressure, low-temperature metamorphism in the Alpujárride nappes, Betic Cordilleras (SE Spain). European Journal of Mineralogy, 1(1): 139-142.

Gueguen, E., Doglioni, C., and Fernández, M. (1998). On the post-25 Ma geodynamic evolution of the Western Mediterranean. Tectonophysics, 298(1-3):259-269.

Guerrera, F., Martín-Algarra, A., and Martín-Martín, M. (2012). Tectono-sedimentary evolution of the 'numidian formation' and lateral facies (southern branch of the Western Tethys): constraints for Central-Western Mediterranean geodynamics. Terra Nova, 24(1):3441.

Gutscher, M.-A., Dominguez, S., Westbrook, G., Roy, P. L., Rosas, F., Duarte, J., Terrinha, P., Miranda, J., Graindorge, D., Gailler, A., Sallares, V., and Bartolome, R. (2012). The Gibraltar subduction: A decade of new geophysical data. Tectonophysics, 574-575:72-91.

Gutscher, M.-A., Malod, J., Rehault, J.-P., Contrucci, I., Klingelhoefer, F., Mendes-Victor, L., and Spakman, W. (2002). Evidence for active subduction beneath Gibraltar. Geology,30:1071-1074.

Hebeda, E., Boelrijk, N., Priem, H., Verdurmen, E., Verschure, R., and Simon, O. (1980). Excess radiogenic Ar and undisturbed $\mathrm{Rb}-\mathrm{Sr}$ systems in basic intrusives subjected to alpine metamorphism in southeastern Spain. Earth and Planetary Science Letters, 47(1):81-90.

Hidas, K., Booth-Rea, G., Garrido, C. J., Martínez-Martínez, J. M., Padrón-Navarta, J. A., Konc, Z., Giaconia, F., Frets, E., and Marchesi, C. (2013). Backarc basin inversion and 
subcontinental mantle emplacement in the crust: kilometre-scale folding and shearing at the base of the proto-Alborán lithospheric mantle (Betic Cordillera, southern Spain). Journal of the Geological Society, 170(1):47-55.

Insua-Arévalo, J.M., Martínez-Díaz, J.J., García-Mayordomo, J. and Martín-González, F. (2012). Active tectonics in the Malaga Basin: evidences from morphotectonic markers (Western Betic Cordillera, Spain). Journal of Iberian Geology, 38(1):175-190.

Iribarren, L., Vergés, J., and Fernández, M. (2009). Sediment supply from the Betic-Rif orogen to basins through Neogene. Tectonophysics, 475(1):68-84.

Jiménez-Bonilla, A., Balanyá, J. C., Expósito, I., and Díaz-Azpiroz, M. (2011). Superposición de estructuras y controles tectónicos en el desarrollo del límite SW de la depresión de Ronda (Subbético y Complejo de Flyschs, Béticas). Geogaceta, 50(1):23-26.

Johanesen, K., Platt, J. P., Kaplan, M. S., and Ianno, A. J. (2014). A revised thermal history of the Ronda Peridotite, S. Spain: New evidence for excision during exhumation. Earth and Planetary Science Letters, 393:187-199.

Jolivet, L., Augier, R., Robin, C., Suc, J.-P., and Rouchy, J. M. (2006). Lithospheric-scale geodynamic context of the Messinian salinity crisis. Sedimentary Geology, 188-189:9-33.

Jolivet, L., Faccenna, C., Huet, B., Labrousse, L., Pourhiet, L. L., Lacombe, O., Lecomte, E., Burov, E., Denéle, Y., Brun, J.-P., Philippon, M., Paul, A., Salaün, G., Karabulut, H., Piromallo, C., Monié, P., Gueydan, F., Okay, A. I., Oberhänsli, R., Pourteau, A., Augier, R., Gadenne, L., and Driussi, O. (2013). Aegean tectonics: Strain localisation, slab tearing and trench retreat. Tectonophysics, 597-598:1-33.

Kirker, A. and Platt, J. P. (1998). Unidirectional slip vectors in the Western Betic Cordillera: implications for the formation of the Gibraltar arc. Journal of the Geological Society, 155(1):193-207.

Kornprobst, J. (1974). Contribution à l'étude pétrographique et structurale de la Zone Interne du Rif (Maroc septentrional). Geological Service of Morocco. 251:1-256. 
Kornprobst, J. (1976). Signification structurale des péridotites dans l'orogéne Bético-Rifain: arguments tirés de l'étude des détritus observés dans les sédiments Paléozoïque. Bulletin de la Societé Géologique de France, 3:607-618.

Koulali, A., Ouazara, D., Tahayt, A., King, R. W., Vernant, P., Reilinger, R., McClusky, S., Mourabit, T., Davila, J. M., and Amraouih, N. (2011). New GPS constraints on active deformation along the Africa-Iberia plate boundary. Earth Planet. Sci. Lett., 308:211-217.

Larouziére, F. D., Bolze, J., Bordet, P., Hernandez, J., Montenat, C., and d'Estevou, P. O. (1988). The Betic segment of the lithospheric trans-Alboran shear zone during the Late Miocene. Tectonophysics, 152(1-2):41-52.

Leblanc, D. (1990). Tectonic adaptation of the external zones around the curved core of an orogen: the Gibraltar arc. Journal of Structural Geology, 12(8):1013-1018.

Lonergan, L. and White, N. (1997). Origin of the Betic-Rif mountain belt. Tectonics, 16:504522.

López-Garrido, A. C. and Sanz de Galdeano, C. (1999). Neogene sedimentation and tectoniceustatic control of the Malaga basin, south Spain. Journal of Petroleum Geology, 22(1):81-96.

Luján, M., Crespo-Blanc, A., and Balanyá, J. C. (2006). The Flysch Trough thrust imbricate (Betic Cordillera): a key element of the Gibraltar arc orogenic wedge. Tectonics, 25:TC6001.

Marchesi, C., Garrido, C. J., Bosch, D., Bodinier, J.-L., Hidas, K., Padrón-Navarta, J.A., and Gervilla, F. (2012) A Late Oligocene Suprasubduction Setting in the Westernmost Mediterranean Revealed by Intrusive Pyroxenite Dikes in the Ronda Peridotite (southern Spain). The Journal of Geology, 120, (2): 237-247.

Marrett, R. and Allmendinger, R. W. (1990). Kinematic analysis of fault-slip data. Journal of structural geology, 12(8):973-986.

Martín, J. M., Braga, J. C., and Betzler, C. (2001). The messinian Guadalhorce corridor: the 
last northern, Atlantic-Mediterranean gateway. Terra Nova, 13(6): 418-424.

Martín-Algarra, A. (1987). Evolución geológica alpina del contacto entre las Zonas Internas y las Zonas Externas de la Cordillera Bética. PhD thesis, Universidad de Granada.

Martín-Algarra, A., Andreo, B., Balanyá, J. C., Estévez, A. C., López-Garrido, A. C., O’Dogherty, L., and García-Dueñas, V. (2004a) Unidades Frontales de las Zonas Internas. . In Vera, J.A., editor, Geología de España, Capítulo IV, pages 396-401. SGE-IGME, Madrid.

Martín-Algarra, A., Balanyá, J. C., Crespo-Blanc, A., Esteras, M., Luján M., Martín-Algarra A., Martín-Martín (2004b). Complejo del Campo de Gibraltar. In Vera, J.A., editor, Geología de España, Capítulo IV, pages 389-395. SGE-IGME, Madrid.

Martín-Algarra, A., Mazzoli, S., Perrone, V., Rodríguez-Cañero, R., and Navas-Parejo, P. (2009). Variscan tectonics in the Malaguide complex (Betic Cordillera, southern Spain): stratigraphic and structural alpine vs. pre-alpine constraints from the Ardales area (province of Malaga). Part I: Stratigraphy. Journal of Geology, 117:241-262.

Martín-Algarra, A. and Vera, J. A. (2004c). El Subbético del sector occidental. In Vera, J.A., editor, Geología de España, Capítulo IV, pages 375-377. SGE-IGME, Madrid.

Martin-Rojas, I., Somma, R., Delgado, F., Estévez, A., Iannace, A., Perrone, V., and Zamparelli, V. (2009). Triassic continental rifting of pangaea: direct evidence from the Alpujarride carbonates, Betic Cordillera, SE Spain. Journal of the Geological Society, 166(3):447-458.

Martin-Rojas, I., Somma, R., Estévez, A., Delgado, F., and Zamparelli, V. (2014). La plataforma Triásica Alpujárride (Zonas Internas de la Cordillera bética, españa). Revista de la Sociedad Geológica de España, 27(1):63-78.

Martínez- García, P., Comas, M., Soto, J. I., Lonergan, L., and Watts, A. B. (2013). Strikeslip tectonics and basin inversion in the Western Mediterranean: the post-Messinian evolution of the Alboran Sea. Basin Research, 25:1-27. 
Martínez-Martínez, J., Torres-Ruiz, J., Pesquera, A., and Gil-Crespo, P. (2010). Geological relationships and $\mathrm{U}-\mathrm{Pb}$ zircon and 40Ar/39Ar tourmaline geochronology of gneisses and tourmalinites from the Nevado-Filabride complex (western Sierra Nevada, Spain): Tectonic implications. Lithos, 119(3-4):238-250.

Mazzoli, S. and Helman, M. L. (1994). Neogene patterns of relative plate motion for AfricaEurope: some implications for recent central Mediterranean tectonics. Geol. Rundsch., $83: 464-468$.

Mazzoli, S. and Martín-Algarra, A. (2011). Deformation partitioning during transpressional emplacement of a 'mantle extrusion wedge': the Ronda Peridotites, Western Betic Cordillera, Spain. Journal of the Geological Society of London, 168:373-382.

Mazzoli, S., Martín-Algarra, A., Reddy, S., Sánchez-Vizcaíno, V. L., Fedele, L., and Noviello, A. (2013). The evolution of the footwall to the ronda subcontinental mantle peridotites: insights from the Nieves Unit (Western Betic Cordillera). Journal of the Geological Society of London, 170:385-402.

Monié, P., Galindo-Zaldívar, J., Lodeiro, F. G., Goffé, B., and Jabaloy, A. (1991). 40Ar/39Ar geochronology of alpine tectonism in the Betic Cordilleras (southern Spain). Journal of the Geological Society, 148(2):289-297.

Monié, P., Torres-Roldán, R., and García-Casco, A. (1994). Cooling and exhumation of the Western Betic Cordillera, 40Ar/39Ar thermochronological constraints on a collapsed terrane. Tectonophysics, 238(1-4):353-379.

Montel, Kornprobst, and Vielzeuf (2000). Preservation of old U-Th-Pb ages in shielded monazite: example from the Beni-Bousera hercynian kinzigites (Morocco). Journal of Metamorphic Geology, 18(3):335-342.

Moreno Serrano, F., Campos Fernández, J., García Rosell, V., Orozco Fernández, M., Sanz de Galdeano, C. (1991). Sheet Ubrique, 1050. Geological map scale 1:50000, Instituto Geológico y Minero de España, Madrid. 
Navarro-Vilá, F. and Tubía, J. (1983). Essai d'une nouvelle différenciation des nappes Alpujarrídes dans le secteur occidental des Cordilléres Bétiques (Andalousie, Espagne). C. R. Acad. Sci. Paris, 296:111-114.

Negro, F., Beyssac, O., Goffé, B., Saddiqi, O., and Bouybaouéne, M. L. (2006). Thermal structure of the Alboran Domain in the Rif (northern Morocco) and the Western Betics (southern Spain). Constraints from Raman spectroscopy of carbonaceous material. Journal of Metamorphic Geology, 24(4):309-327.

Obata, M. (1980). The Ronda peridotite: garnet-, spinel-, and plagioclase-lherzolite facies and the P-T trajectories of a high-temprature mantle intrusion. Journal of Petrology, 21(3):533572.

O'Dogherty, L., Martín-Algarra, A., Gursky, H., and Aguado, R. (2001). The Middle Jurassic radiolarites and pelagic limestones of the Nieves Unit (Rondaide complex, Betic Cordillera): basin starvation in a rifted marginal slope of the Western Tethys. Geologische Rundschau, 90:831-846.

Olivier, P. (1981). L'accident de Jebha-Chrafate (Rif, Maroc). Revue de Géographie Physique et Géologie Dynamique, 23:27-106.

Olivier, P. (1984). Evolution de la limite entre Zones Internes et Zones Externes dans l'arc de Gibraltar (Maroc, Espagne). PhD thesis, Université de Toulouse.

Olivier, P. and Leblanc, D. (1984). The role of strike-slip faults in the Betic-Rifian orogeny. Tectonophysics, 101:345-355.

Pacquet, J. (1969). Étude géologique de l'ouest de la province de Murcie (Espagne). Mém. Soc. Géol. Fr., 48(111):1-270.

Padrón-Navarta, J., López Sánchez-Vizcaíno, V., Garrido, C., Gómez-Pugnaire, M., Jabaloy, A., Capitani, G., and Mellini, M. (2008). Highly ordered antigorite from Cerro del Almirez HP-HT serpentinites, SE Spain. Contributions to Mineralogy and Petrology, 156(5):679-688. 
Palomeras, I., Thurner, S., Levander, A., Liu, K., Villasenor, A., Carbonell, R., and Harnafi, M. (2014). Finite-frequency Rayleigh wave tomography of the western Mediterranean: Mapping its lithospheric structure. Geochemistry, Geophysics, Geosystems, 15(1):140-160.

Pedrera, A., Ruiz-Constán, A., Galindo-Zaldívar, J., Chalouan, A., Sanz de Galdeano, C., Martín-Lechado, C., Ruano, P., Benmakhlouf, M., Akil, M., López-Garrido, A., Chabli, A., Ahmamou, M., and González-Castillo, L. (2011). Is there an active subduction beneath the Gibraltar orogenic arc? Constraints from Pliocene to present-day stress field. Journal of Geodynamics, 52(2):83-96.

Pedrera, A., Marín-Lechado, C., Martos-Rosillo, S. and Roldán, F.J. (2012). Curved foldand-thrust accretion during the extrusion of a synorogenic viscous allochthonous sheet: The Estepa Range (External Zones, Western Betic Cordillera, Spain). Tectonics, 31 : TC4013.

Pérouse, E., Vernant, P., Chéry, J., Reilinger, R., and McClusky, S. (2010). Active surface deformation and sub-lithospheric processes in the Western Mediterranean constrained by numerical models. Geology, 38(9):823-826.

Perri, F., Critelli, S., Martín-Algarra, A., Martín-Martín, M., Perrone, V., Mongelli, G., and Zattin, M. (2013). Triassic redbeds in the Malaguide complex (Betic Cordillera, Spain): Petrography, geochemistry and geodynamic implications. Earth-Science Reviews, 117:1-28.

Piles Mateo, E., Chamón Cobos, C., Estevéz González, C., Crespo, V., Aguilar, M., and Reyes, J.L. (1972a). Sheet Marbella, 1065. Geological map scale 1:50000, Instituto Geológico y Minero de España, Madrid.

Piles Mateo, E., Estevéz González, C., Barba Martín, A. (1972b). Sheet Coín, 1066. Geological map scale 1:50000, Instituto Geológico y Minero de España, Madrid.

Pineda, A. (1983). Sheet Archidona, 1024. Geological map scale 1:50000, Instituto Geológico y Minero de España, Madrid. 
Platt, J. P., Allerton, S., Kirker, A., Mandeville, C., Mayfield, A., Platzman, E., and Rimi, A. (2003a). The ultimate arc: Differential displacement, oroclinal bending, and vertical axis rotation in the External Betic-Rif arc. Tectonics, 22(3):1017. doi: 10.1029/2001TC001321

Platt, J. P., Anczkiewicz, R., Soto, J.-I., Kelley, S. P., and Thirlwall, M. (2006). Early Miocene continental subduction and rapid exhumation in the western Mediterranean. Geology, 34(11):981-984.

Platt, J. P., Argles, T., Carter, A., Kelley, S., Whitehouse, M., and Lonergan, L. (2003b). Exhumation of the Ronda Peridotites and its crustal envelope: constraints from thermal modelling of a P-T-time array. Journal of the Geological Society, 160(5):655-676.

Platt, J. P., Behr, W. M., Johanesen, K., and Williams, J. R. (2013). The Betic-Rif arc and its orogenic hinterland: A review. Annual Review of Earth and Planetary Sciences, 41(1):313357.

Platt, J. P., Behrmann, J., Martínez, J.-M., and Vissers, R. L. M. (1984). A zone of mylonite and related ductile deformation beneath the Alpujarride nappe complex, Betic Cordilleras, S. Spain. Geologische Rundschau, 73(2):773-785.

Platt, J. P., Houseman, G., Gutscher, M.-A., Malod, J., Rehault, J.-P., Contrucci, I., Klingelhoefer, F., Mendes-Victor, L., and Spakman, W. (2003c). Evidence for active subduction beneath Gibraltar: Comment and Reply. Geology, 31(1): 22-23.

Platt, J. P., Kelley, S., Carter, A., and Orozco, M. (2005). Timing of tectonic events in the Alpujárride complex, Betic Cordillera, southern Spain. Journal of the Geological Society, 162(3):451-462.

Platt, J. P. and Vissers, R. L. M. (1989). Extensional collapse of thickened continental lithosphere: A working hypothesis for the Alboran Sea and Gibraltar arc. Geology, 17:540543.

Platt, J. P., and Whitehouse, M. (1999). Early Miocene high-temperature metamorphism and rapid exhumation in the Betic Cordillera (Spain): evidence from U-Pb zircon ages. Earth and 
Planetary Science Letters, 171(4):591-605.

Platt, J. P., Whitehouse, M., Kelley, S., Carter, A., and Hollick, L. (2003d). Simultaneous extensional exhumation across the Alboran Basin: implications for the causes of late orogenic extension. Geology, 31(3):251-254.

Platzman, E. and Lowrie, W. (1992). Paleomagnetic evidence for rotation of the Iberian peninsula and the External Betic Cordillera, southern Spain. Earth and Planetary Science Letters, 108(1-3):45-60.

Platzman, E., Platt, J. P., Kelley, S. P., and Allerton, S. (2000). Large clockwise rotations in an extensional allochton, Alboran Domain (southern Spain). Journal of the Geological Society, London, 157: 1187-1197.

Précigout, J., Gueydan, F., Garrido, C. J., Cogné, N., and Booth-Rea, G. (2013). Deformation and exhumation of the Ronda Peridotite (Spain). Tectonics, 32(4):1011-1025.

Puga, E., Fanning, M., de Federico, A. D., Nieto, J. M., Beccaluva, L., Bianchini, G., and Puga, M. A. D. (2011). Petrology, geochemistry and U-Pb geochronology of the Betic ophiolites: Inferences for pangaea break-up and birth of the westernmost tethys ocean. Lithos, 124(3-4):255-272.

Puga, E., Nieto, J., Díaz de Federico, A., Bodinier, J., and Morten, L. (1999). Petrology and metamorphic evolution of ultramafic rocks and dolerite dikes of the Betic ophiolite association (Mulhacen complex, SE Spain): evidence of eo-alpine subduction following an ocean- floor metasomatic process. Lithos, 49:23-56.

Rosenbaum, G. and Lister, G. S. (2004). Formation of arcuate orogenic belts in the western Mediterranean region. Geological Society of America Special Papers, 383:41-56.

Rosenbaum, G., Lister, G. S., Duboz, C., et al. (2002). Reconstruction of the tectonic evolution of the Western Mediterranean since the Oligocene. Journal of the Virtual Explorer, 8:107-130. 
Rossetti, F., Faccenna, C., and Crespo-Blanc, A. (2005). Structural and kinematic constraints of the Alpujarride complex (central Betic Cordillera, Spain). J. Struct. Geol., 27:199-216.

Royden, L. H. (1993). Evolution of retreating subduction boundaries formed during continental collision. Tectonics, 12:629-638.

Ruiz-Constán, A., Galindo-Zaldívar, J., Pedrera, A., and Sanz de Galdeano, C. (2009). Gravity anomalies and orthogonal box fold development on heterogeneous basement in the neogene Ronda depression (Western Betic Cordillera). Journal of Geodynamics, 47(4):210217.

Ruiz-Constán, A., Pedrera, A., Galindo-Zaldívar, J., Pous, J., Arzate, J., Roldán-García, F., Marin-Lechado, C., and Anahnah, F. (2012a). Constraints on the frontal crustal structure of a continental collision from an integrated geophysical research: The central-Western Betic Cordillera (SW Spain). Geochemistry, Geophysics, Geosystems, 13(8): Q08012.

Ruiz-Constán, A., Pedrera, A., Galindo-Zaldívar, J., Stich, D., Morales, J. (2012b). Recent and active tectonics in the western part of the Betic Cordillera. Journal of Iberian Geology, 38(1):161-174.

Ruiz Cruz, M. D. and Sanz de Galdeano, C. (2014). Garnet variety and zircon ages in UHP meta-sedimentary rocks from the Jubrique Zone (Alpujárride complex, Betic Cordillera, Spain): evidence for a pre-alpine emplacement of the Ronda Peridotites. International Geology Review, 56(7):845-868.

Rutter, E., Faulkner, D., and Burgess, R. (2012). Structure and geological history of the Carboneras fault zone, SE Spain: Part of a stretching transform fault system. Journal of Structural Geology, 45:68-86.

Sánchez-Gómez, M., Balanyá, J. C., García-Dueñas, V., and Azañón, J. M. (2002). Intracrustal tectonic evolution of large lithosphere mantle slabs in the western end of the Mediterranean orogen (Gibraltar arc). Journal of the Virtual Explorer, 8:23-34.

Sánchez-Gómez, M., Azañón, J. M., García-Dueñas, V., and Soto, J. I. (1999). Correlation 
between metamorphic rocks recovered from site 976 and the Alpujárride rocks of the Western Betics. In Zahn, R., Comas, M. C. and Klaus, A., editors, Proceedings of the Ocean Drilling Program, Scientific Results, pages 307-317.

Sánchez-Navas, A., García-Casco, A., and Martín-Algarra, A. (2014). Pre-alpine discordant granitic dikes in the metamorphic core of the Betic Cordillera: tectonic implications. Terra Nova, 26 (6):477-486.

Sánchez-Rodríguez, L. (1998). Pre-Alpine and Alpine evolution of the Ronda Ultramafic Complex and its country-rocks (Betic chain, southern Spain): U-Pb SHRIMP zircon and fission-track dating. PhD thesis, Swiss Federal Institute of Technology Zürich.

Sánchez-Rodríguez, L. and Gebauer, D. (2000). Mesozoic formation of pyroxenites and gabbros in the Ronda area (southern Spain), followed by Early Miocene subduction metamorphism and emplacement into the middle crust: U-Pb sensitive high-resolution ion microprobe dating of zircon. Tectonophysics, 316(1-2):19-44.

Sanz de Galdeano, C. (1990). Geologic evolution of the Betic Cordilleras in the Western Mediterranean, Miocene to the present. Tectonophysics, 172(1-2):107-119.

Sanz De Galdeano, C. (1996). The E-W segments of the contact between the External and Internal Zones of the Betic and Rif Cordillera and the E-W corridors of the Internal Zone (a combined explanation). Estudios Geológicos, 52:123-136.

Sanz De Galdeano, C. (2012). Génesis de la estructura arqueada de la Sierra de las Cabras al Gibalto (Subbético, provincias de Málaga y Granada, España). Estudios Geológicos, 68(2):179-187.

Sanz de Galdeano, C. and Andreo, B. (1995). Structure of Sierra Blanca (Alpujarride complex, west of the Betic Cordillera). Estudios Geológicos, 51:43-55.

Sanz de Galdeano, C., Andreo, B., and López-Garrido, A.-C. (2001a). Comment on the paper "Late exhumation stages of the Alpujarride complex (Western Betic Cordilleras, Spain): new thermochronological and structural data on Los Reales and Ojen nappes" by Marc Sosson, 
Anne-Claire Morillon, Jacques Bourgois, Gilbert Féraud, Gérard Poupeau, Pierre Saint-Marc. Tectonophysics, 331(4):413-417.

Sanz de Galdeano, C., Andreo, B., García-Tortosa, F., and López-Garrido, A. C. (2001b). The Triassic paleogeographic transition between the Alpujarride and Malaguide complexes, BeticRif Internal Zone (S Spain, N Morocco). Palaeogeography, Palaeoclimatology, Palaeoecology, 167:157-173.

Sanz de Galdeano, C. and López-Garrido, A.C. (2012a). Tectónica de las sierras penibéticas de Abdalajís y de Huma (provincia de Málaga, España). Su relación con el contacto con la Zona Interna. Estudios Geológicos, 69(2):133-147.

Sanz de Galdeano, C. and López-Garrido, A.C. (2012b). The Torcal de Antequera, an example of a structure formed by a large scale dextral transcurrent system. Estudios Geológicos, 68(2):189-202.

Sanz de Galdeano, C., López-Garrido, A. C., and Andreo, B. (1999). The stratigraphic and tectonic relationships of the Alpujarride and Malaguide complexes in the Western Betic Cordillera (Casares, prov. of Malaga, southern Spain). Comptes Rendus de l'Académie des Sciences, Série 2, Mécanique, Physique, Chimie, Sciences de l'Univers, Sciences de la Terre, 328(2):113-119.

Sanz de Galdeano, C., Lozano, J. A., and Puga, E. (2008). El "Trías de Antequera"” naturaleza, origen y estructura. Revista de la Sociedad Geológica de España, 21(3-4):111-124.

Schettino, A. and Turco, E. (2011). Tectonic history of the Western Tethys since the late Triassic. Geological Society of America Bulletin, 123(1-2):89-105.

Seber, D., M. Barazangi, A. Ibenbrahimt, and B. Ahmed (1996), Geophysical evidence for lithospheric delamination beneath the Alboran Sea and Rif-Betic mountains, Nature, 379: 785-790.

Serrano, F., Guerra-Merchán, A., Kadiri, K. E., Sanz de Galdeano, C., López-Garrido, A. C., Martín-Martín, M., and Hlila, R. (2007). Tectono-sedimentary setting of the Oligocene-Early 
Miocene deposits on the Betic-Rifian Internal Zone (Spain and Morocco). Geobios, 40(2):191-205.

Sosson, M., Morrillon, A.-C., Bourgois, J., Féraud, G., Poupeau, G., and Saint-Marc, P. (1998). Late exhumation stages of the Alpujarride complex (western Betic Cordilleras, Spain): new thermochronological and structural data on Los Reales and Ojen nappes. Tectonophysics, 285(3-4):253-273.

Spakman, W. and Wortel, R. (2004). A tomographic view on the Western Mediterranean geodynamics. In Cavazza, W., Roure, F., Spakman, W., Stampfli, G., and Ziegler, P., editors, The TRANSMED Atlas. The Mediterranean Region from Crust to Mantle, pages 31-52, Berlin/Heidelberg. Springer.

Stromberg, S. G. and Bluck, B. (1998). Turbidite facies, fluid-escape structures and mechanisms of emplacement of the oligo-miocene Aljibe Flysch, Gibraltar arc, betics, southern Spain. Sedimentary Geology, 115(1-4):267-288.

Suades, E. and Crespo-Blanc, A. (2013). Gravitational dismantling of the Miocene mountain front of the Gibraltar Arc system deduced from the analysis of an olistostromic complex. Geologica Acta, 11(2):215-229.

Thurner, S., Palomeras, I., Levander, A., Carbonell, R., and Lee, C.-T. (2014). Ongoing lithospheric removal in the western Mediterranean: Evidence from Ps receiver functions and thermobarometry of Neogene basalts (PICASSO Project). Geochemistry, Geophysics, Geosystems, 15(4):1113-1127.

Thurow, J. and Kuhnt, W. (1986). Mid-Cretaceous of the Gibraltar arc area. Geological Society, London, Special Publications, 21(1):423-445.

Torres-Roldán, R. L. (1979). The tectonic subdivision of the Betic Zone (Betic Cordilleras, southern Spain); its significance and one possible geotectonic scenario for the westernmost alpine belt. American Journal of Science, 279(1):19-51.

Tubía, J., Cuevas, J., and Esteban, J. (2004). Tectonic evidence in the Ronda Peridotites, 
Spain, for mantle diapirism related to delamination. Geology, 32(11):941-944.

Tubía, J., Cuevas, J., and Esteban, J. (2013). Localization of deformation and kinematic shift during the hot emplacement of the Ronda Peridotites (Betic Cordilleras, southern Spain). Journal of Structural Geology, 50:148-160.

Tubía, J., Cuevas, J., Esteban, J., and Ibarguchi, J. G. (2009). Remnants of a Mesozoic rift in a subducted terrane of the Alpujarride complex (Betic Cordilleras, southern Spain). The Journal of Geology, 117(1):71-87.

Tubía, J., Cuevas, J., and Ibarguchi, J. G. (1997). Sequential development of the metamorphic aureole beneath the Ronda Peridotites and its bearing on the tectonic evolution of the Betic Cordillera. Tectonophysics, 279(1):227-252.

Tubía, J., Cuevas, J., Navarro-Vilá, F., Alvarez, F., and Aldaya, F. (1992). Tectonic evolution of the Alpujárride complex (Betic Cordillera, southern Spain). Journal of structural geology, 14(2):193-203.

Van der Wal, D. and Vissers, R. L. M. (1993). Uplift and emplacement of upper mantle rocks in the Western Mediterranean. Geology, 21(12):1119-1122.

Van Hinsbergen, D. J. J., Vissers, R. L. M., and Spakman, W. (2014). Origin and consequences of Western Mediterranean subduction, rollback, and slab segmentation. Tectonics, 33(4):393-419.

Vera, J. A., Arias, C., García-Hernández, M., López-Garrido, A., Martín-Algarra, A., MartínChivelet, J., Molina, J., Rivas, P., Ruiz-Ortiz, P., Sanz de Galdeano, C., and Vilas, L. (2004). Las Zonas Externas Béticas y el Paleomargen Sudibérico. In Vera, J.A., editor, Geología de España, Capítulo IV, pages 354-361. SGE-IGME, Madrid.

Vergés, J. and Fernández, M. (2012). Tethys-Atlantic interaction along the Iberia-Africa plate boundary: The Betic-Rif orogenic system. Tectonophysics, 579 (5): 144-172.

Vernant, P., Fadil, A., Mourabit, T., Ouazar, D., Koulali, A., Davila, J.M., Garate, J., 
McClusky, S., Reilinger, R.E. (2010). Geodetic constraints on active tectonics of the Western Mediterranean: implications for the kinematics and dynamics of the Nubia-Eurasia plate boundary zone. Journal of Geodynamics, 49: 123-129.

Villalaín, J., Osete, M., Vegas, R., García-Dueñas, V., and Heller, F. (1994). Widespread neogene remagnetization in Jurassic limestones of the south-iberian palaeomargin (Western Betics, Gibraltar arc). Physics of the Earth and Planetary Interiors, 85(1-2):15-33.

Villasante-Marcos, V., Osete, M. L., Gervilla, F., and García-Dueñas, V. (2003) Paleomagnetic study of the Ronda peridotites (Betic Cordillera, southern Spain). Tectonophysics, 377:119-141.

Vissers, R. L. M. and Meijer, P. (2012). Iberian plate kinematics and alpine collision in the pyrenees. Earth-Science Reviews, 114(1-2):61-83.

Vitale, S., Zaghloul, M. N., Tramparulo, F. D., and Ouaragli, B. E. (2014a). Deformation characterization of a regional thrust zone in the northern Rif (Chefchaouen, Morocco). Journal of Geodynamics, 77:22-38.

Vitale, S., Zaghloul, M. N., Tramparulo, F. D., Ouaragli, B. E., and Ciarcia, S. (2014b). From Jurassic extension to Miocene shortening: An example of polyphasic deformation in the external Dorsale Calcaire unit (Chefchaouen, Morocco). Tectonophysics, 633:63-76.

Wildi, W., Nold, M., and Uttinger, J. (1977) La Dorsale Calcaire entre Tétouan et Asifane (Rif Interne, Maroc). Eclogae geol. Helv., 770:371-416.

Wortel, M. J. R. and Spakman, W. (2000). Subduction and slab detachment in the Mediterranean-Carpathian region. Science, 209:1910-1917.

Zeck, H. P. and Whitehouse, M. J. (2002). Repeated age resetting in zircons from HercynianAlpine polymetamorphic schists (Betic - Rif tectonic belt, S. Spain) - a U-Th-Pb ion microprobe study. Chemical geology, 182:275-292. 


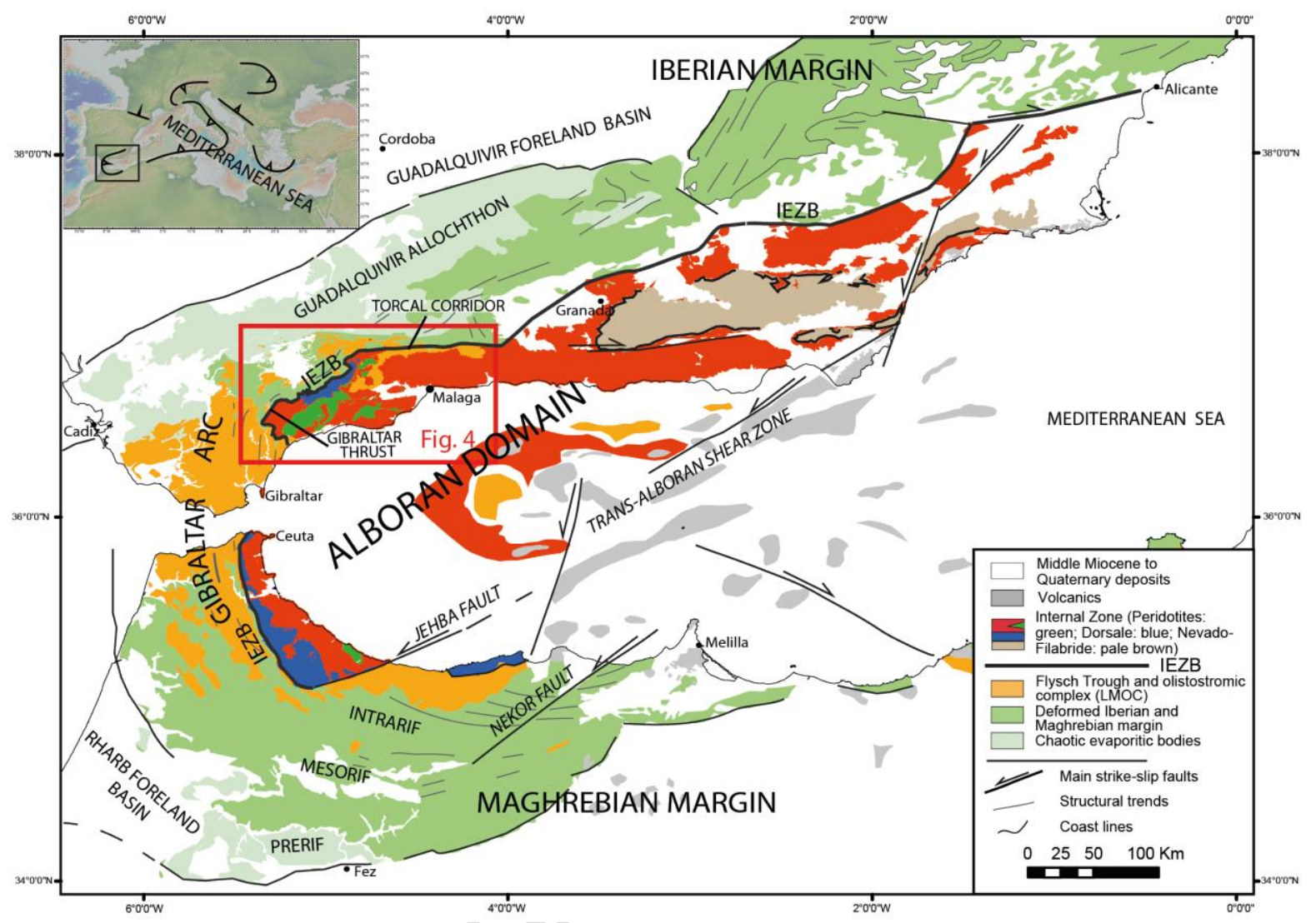

Figure 1 


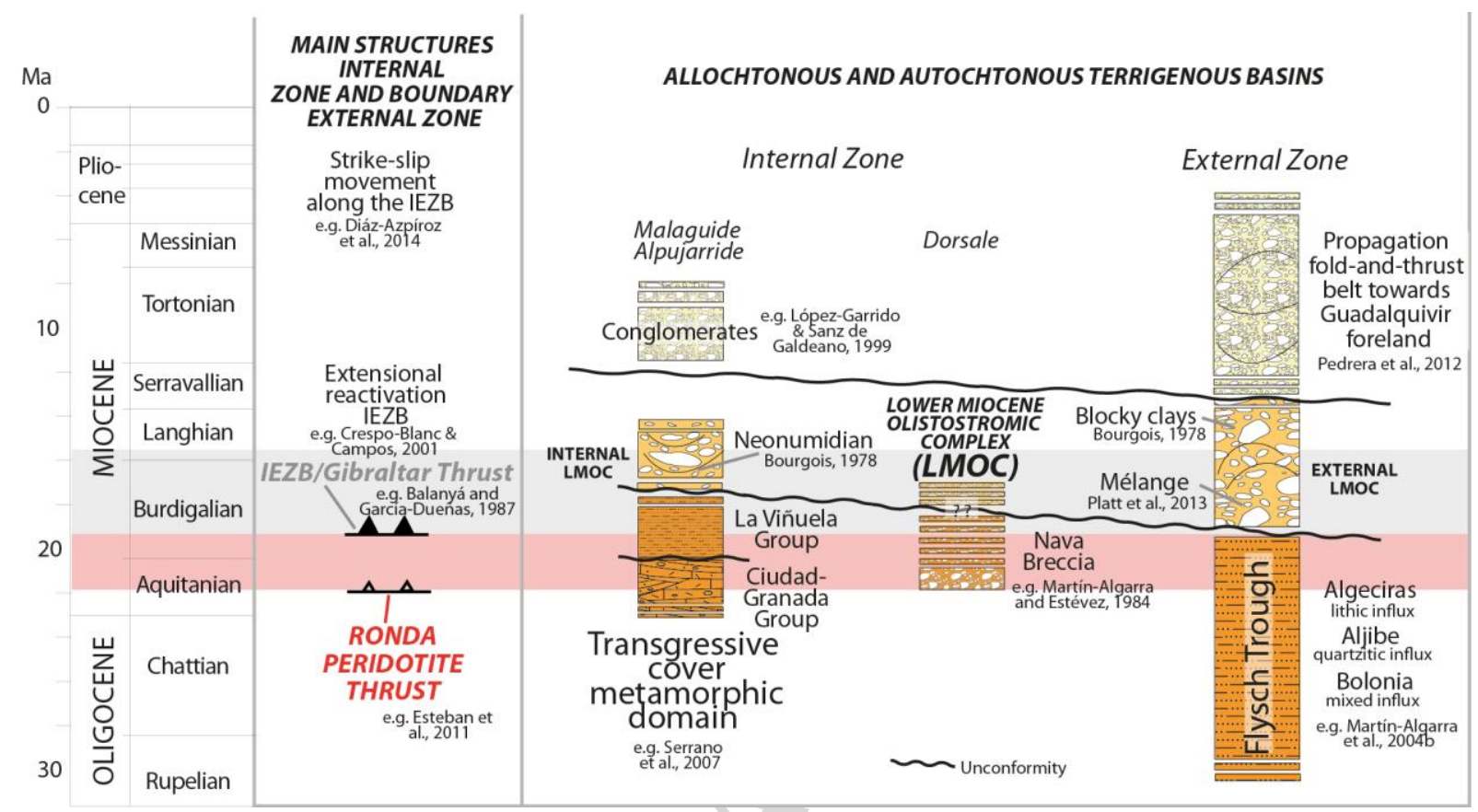

Figure 2 


\section{ALBORAN DOMAIN DISPLACEMENT DURING LOWER MIOCENE (W. BETICS)}

Platt et al., 2003a

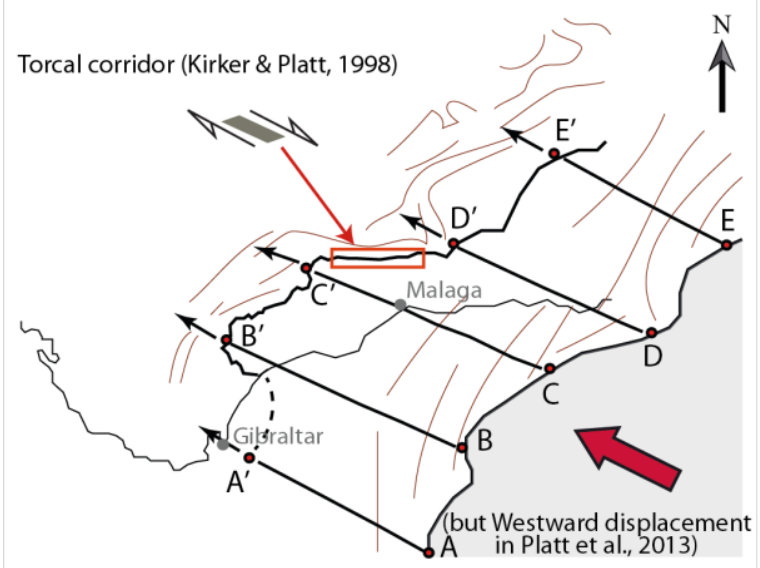

Balanyá et al., 2007

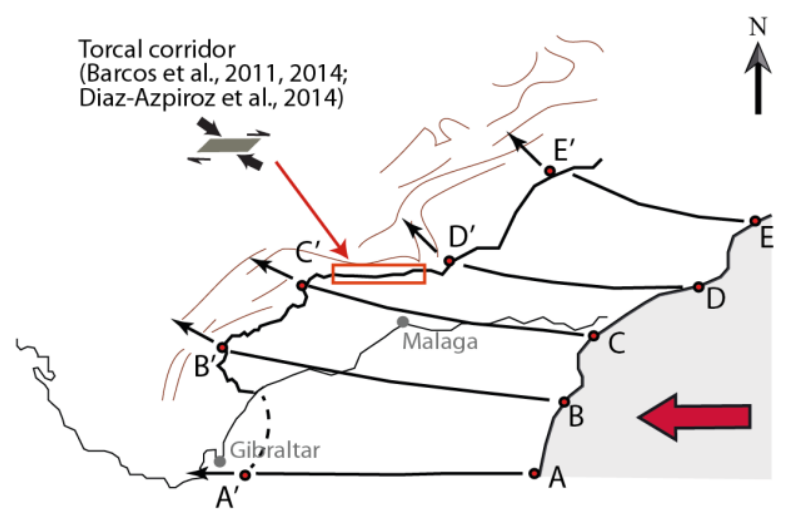

Figure 3 


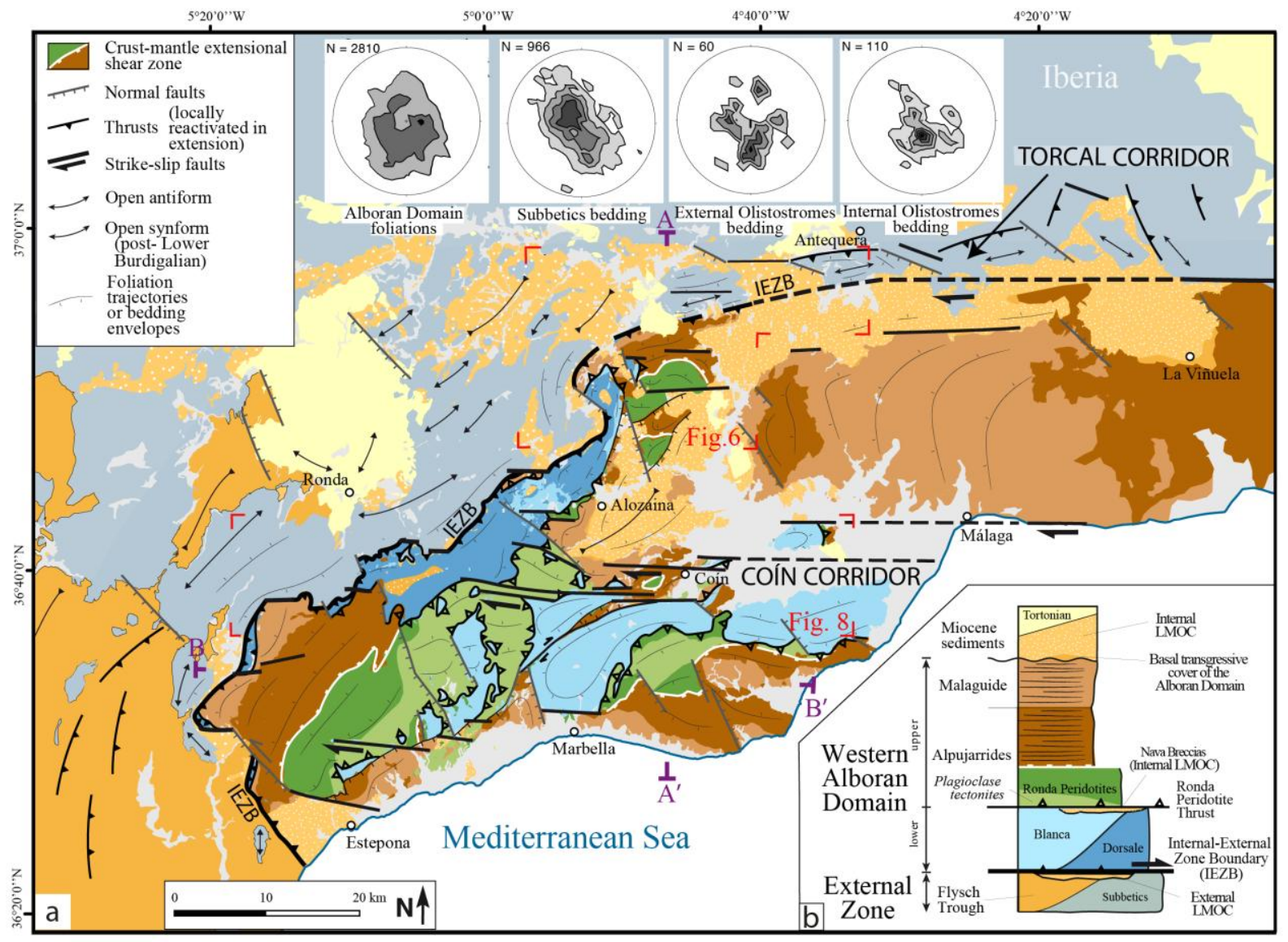

Figure 4 

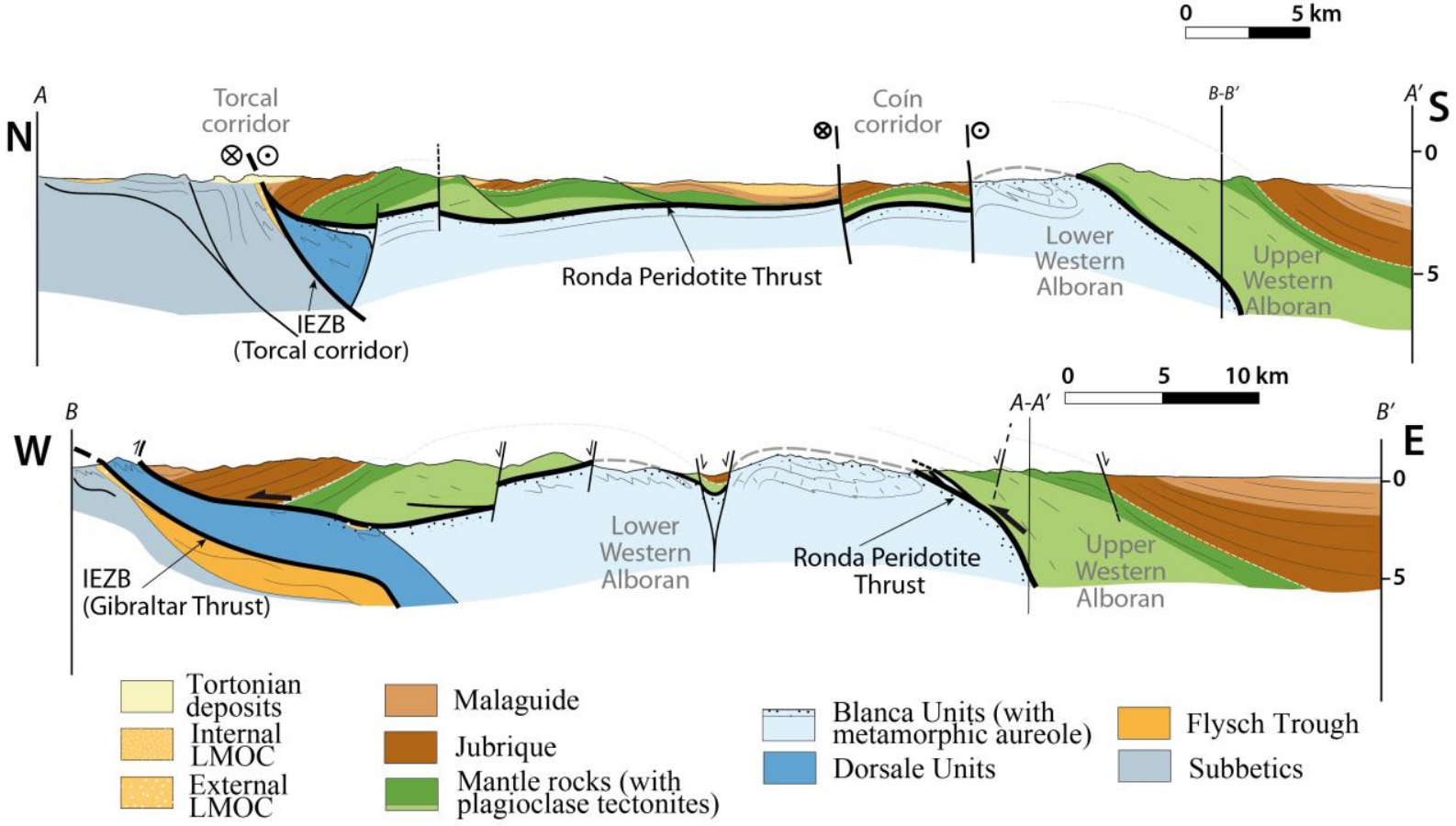

Figure 5 


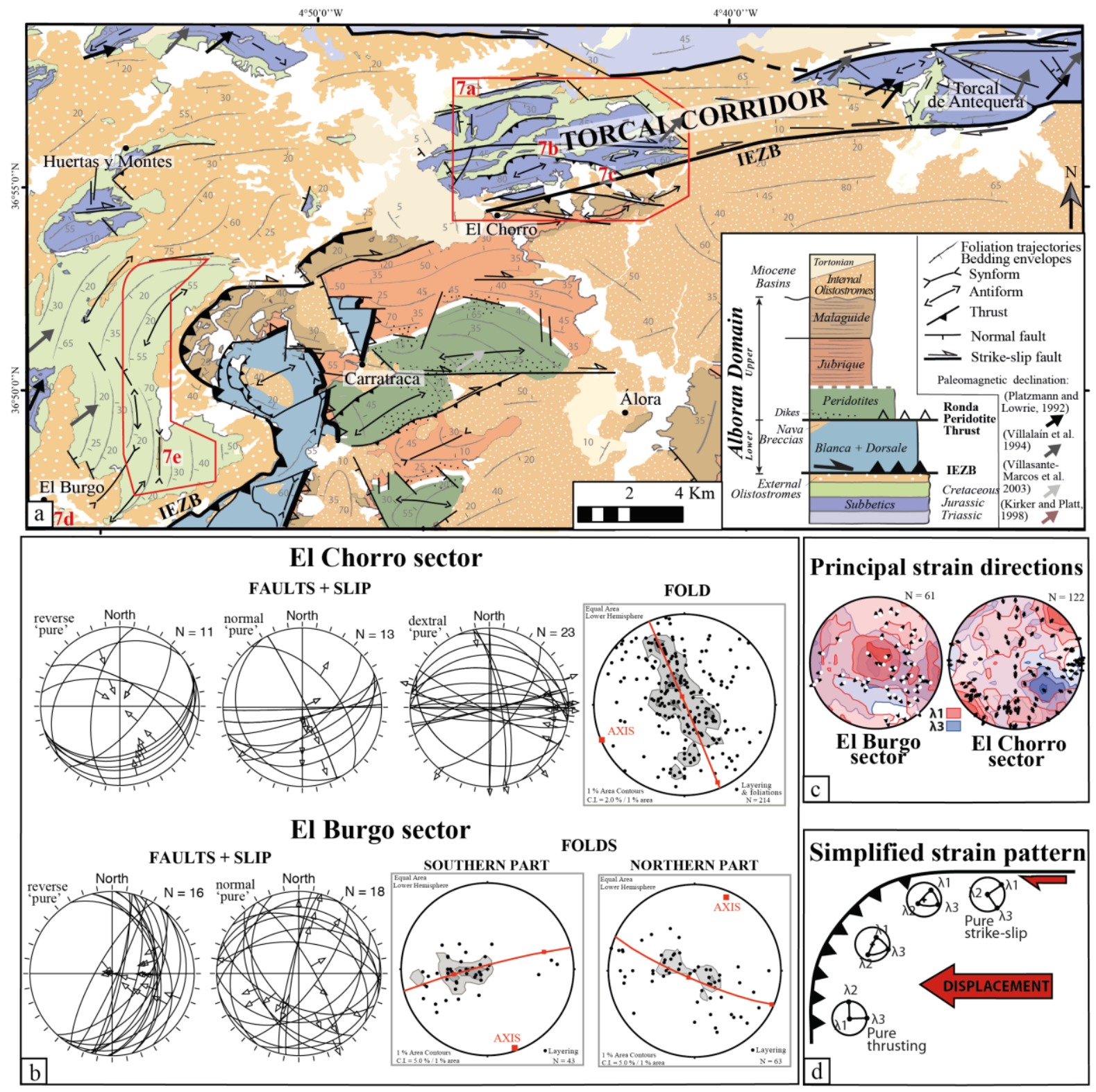

Figure 6 

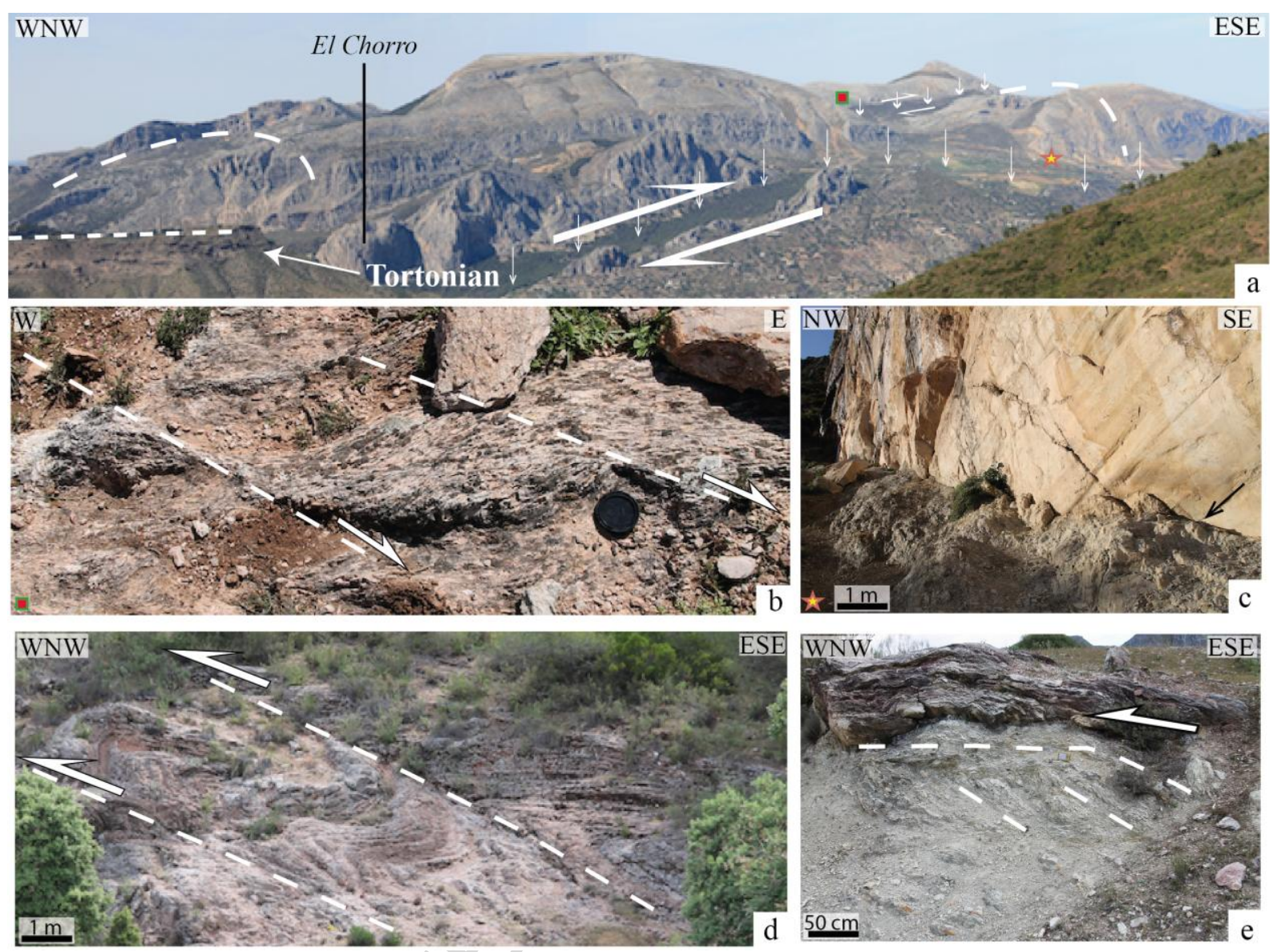

Figure 7 

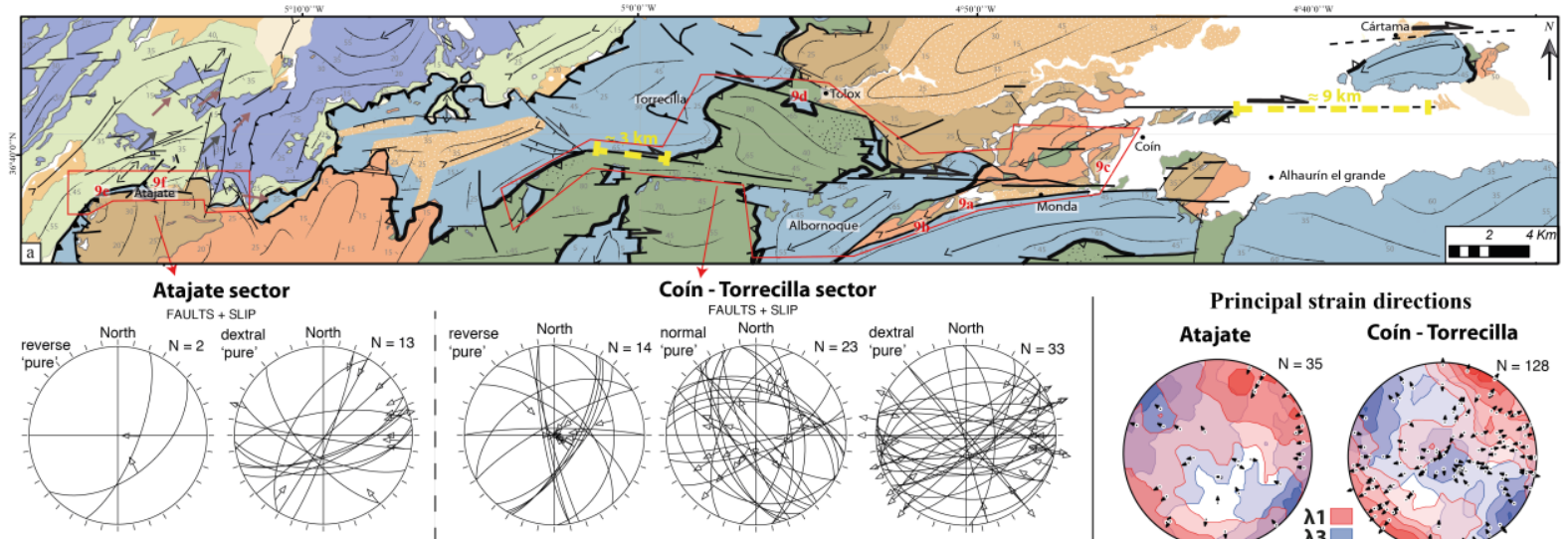

Principal strain directions

Atajate Coin - Torrecilla
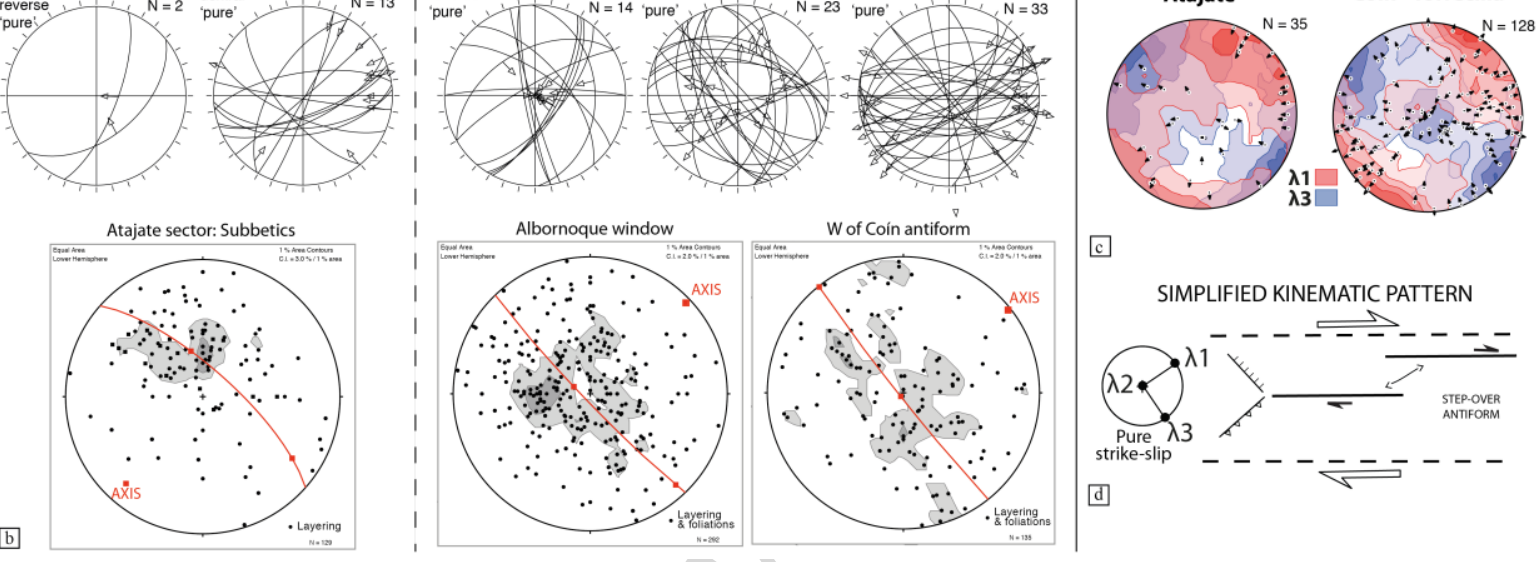

c.

SIMPLIFIED KINEMATIC PATTERN

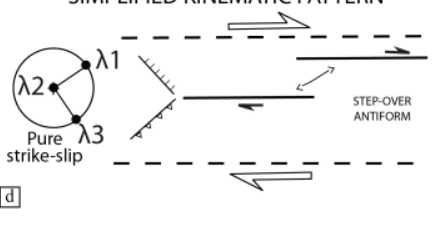

Figure 8 

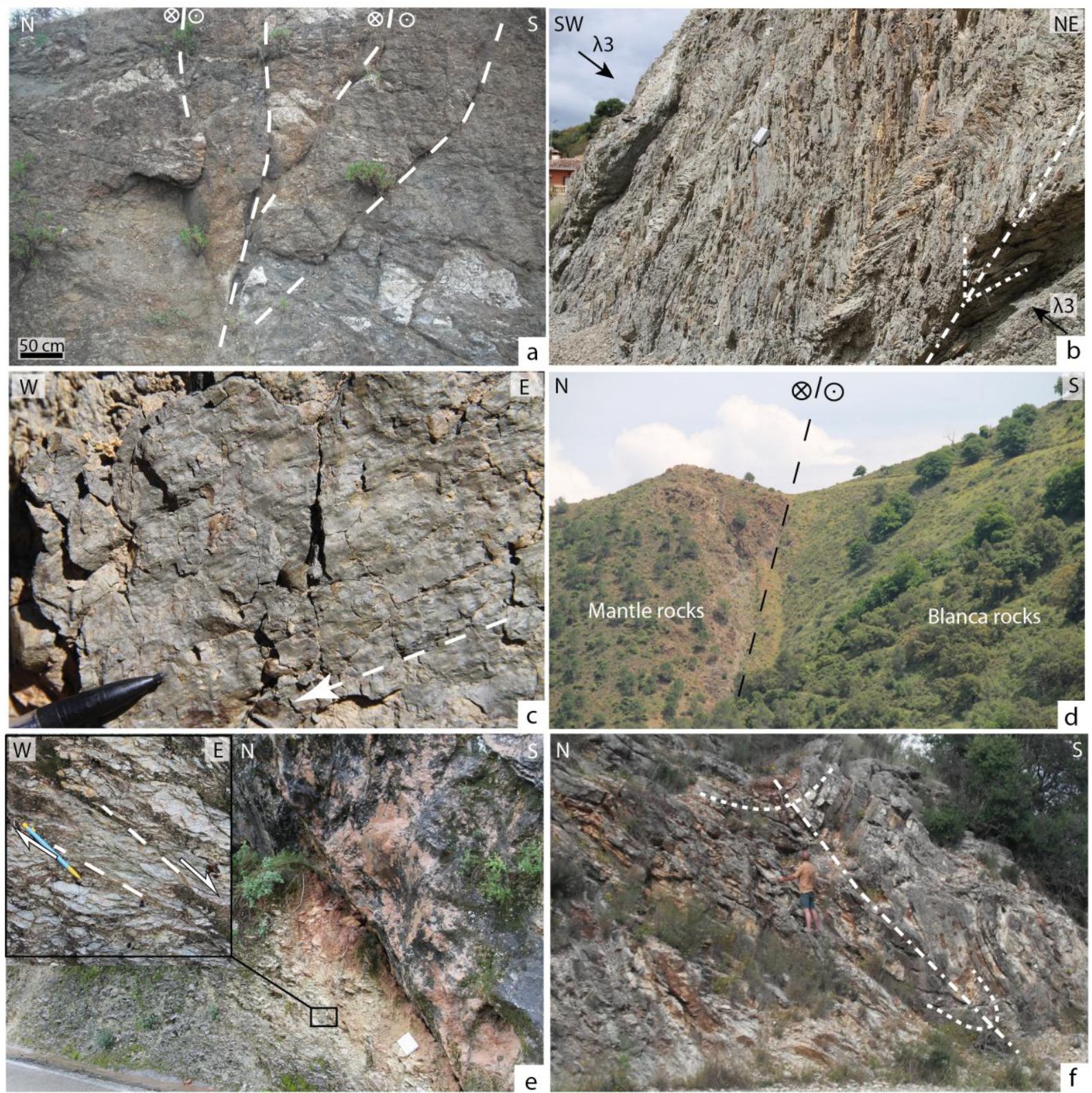

Figure 9 
15-0 Ma: Westward migration of the active front

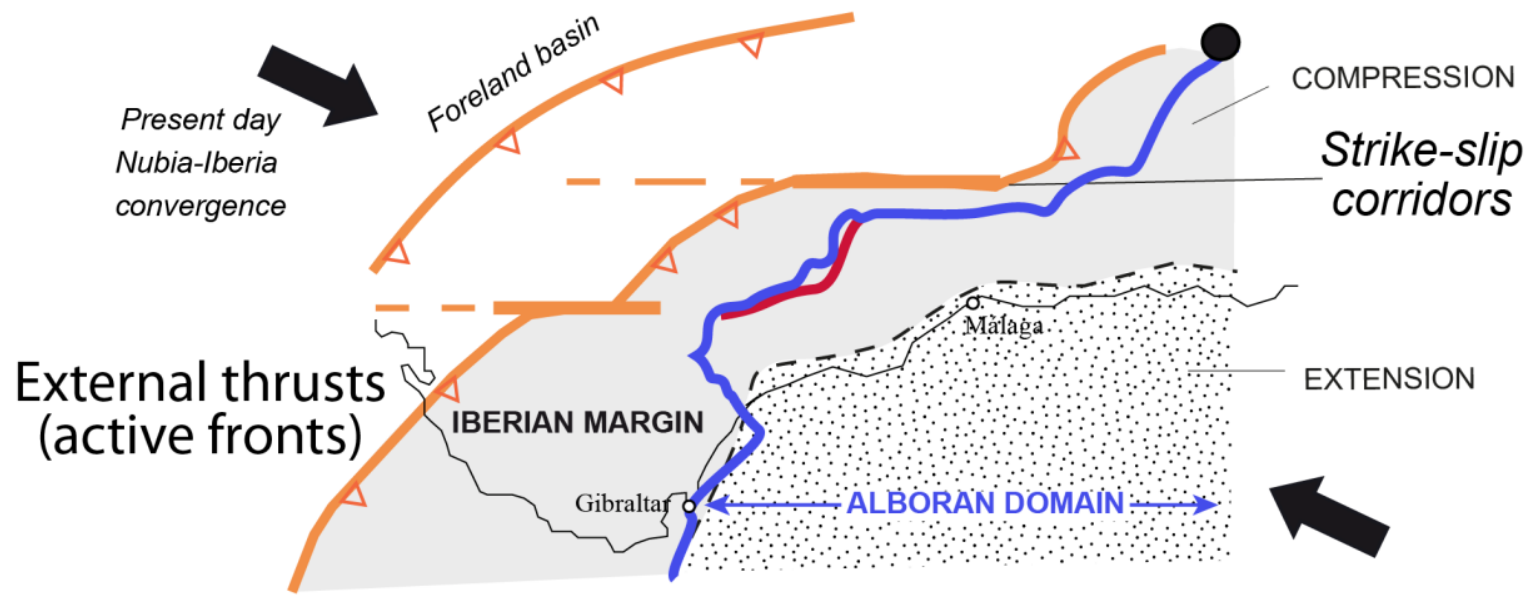

$40 \mathrm{~km}$

21-15 Ma: Thrusting and strike-slip corridors in the Alboran Domain

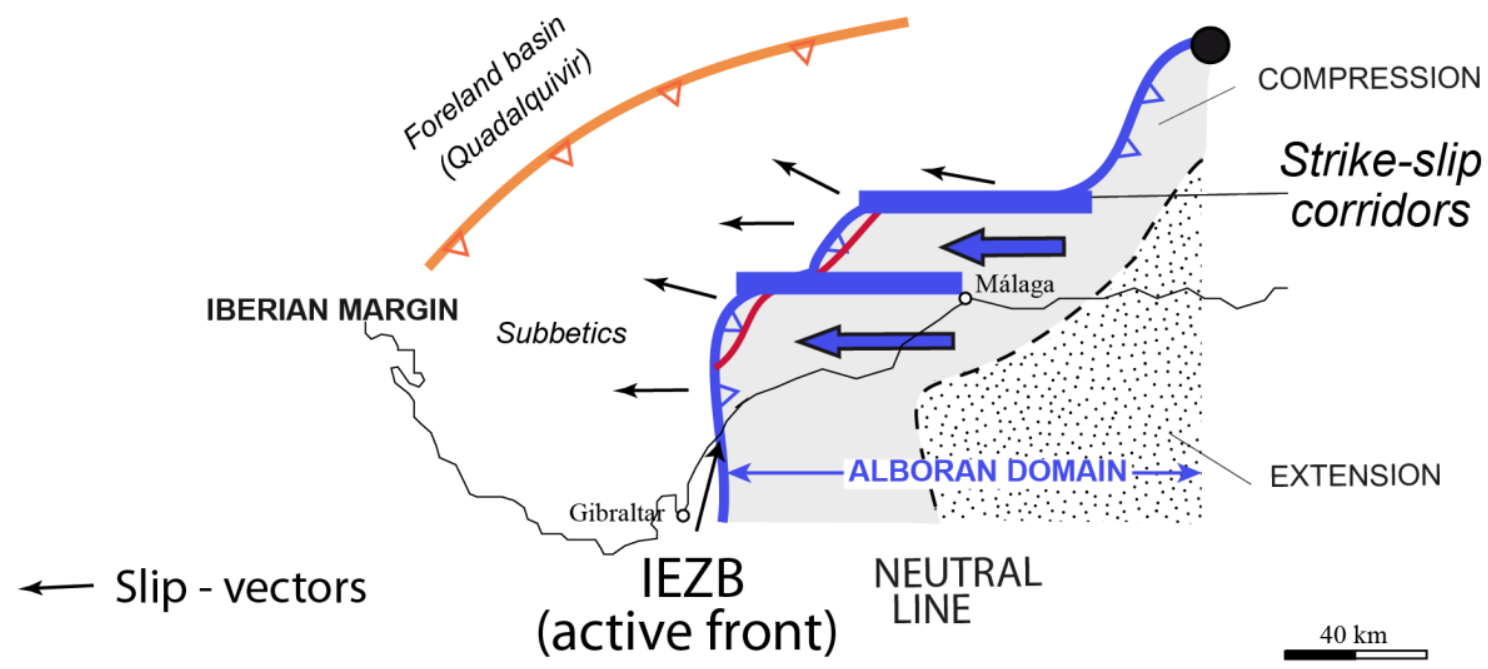

22-20 Ma: Onset of westward motion

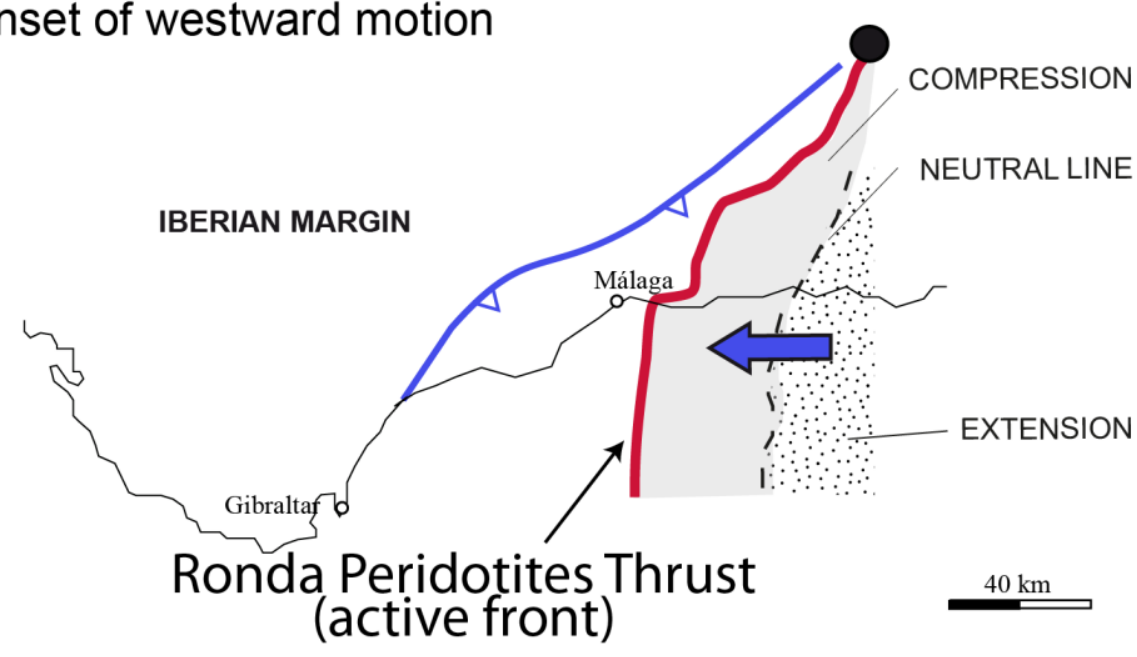

Figure 10 
15-0 Ma: Westward migration of the active front

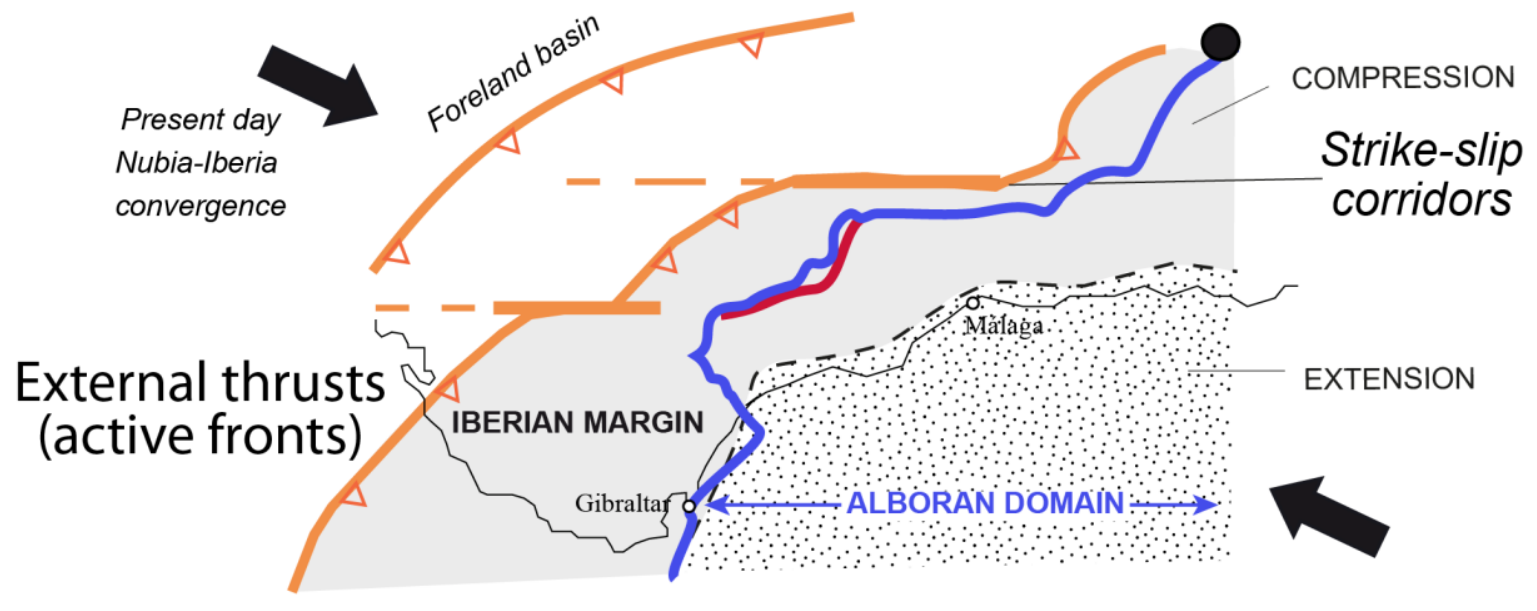

$40 \mathrm{~km}$

21-15 Ma: Thrusting and strike-slip corridors in the Alboran Domain

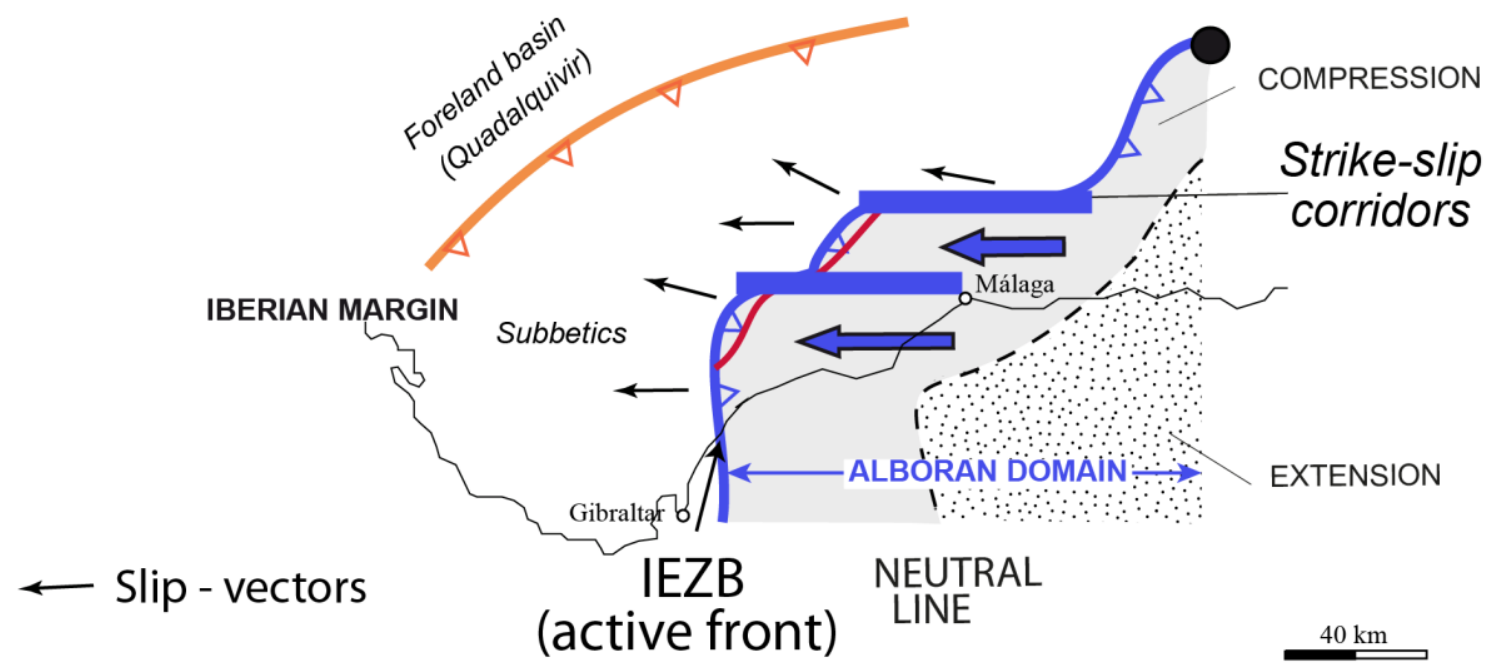

22-20 Ma: Onset of westward motion

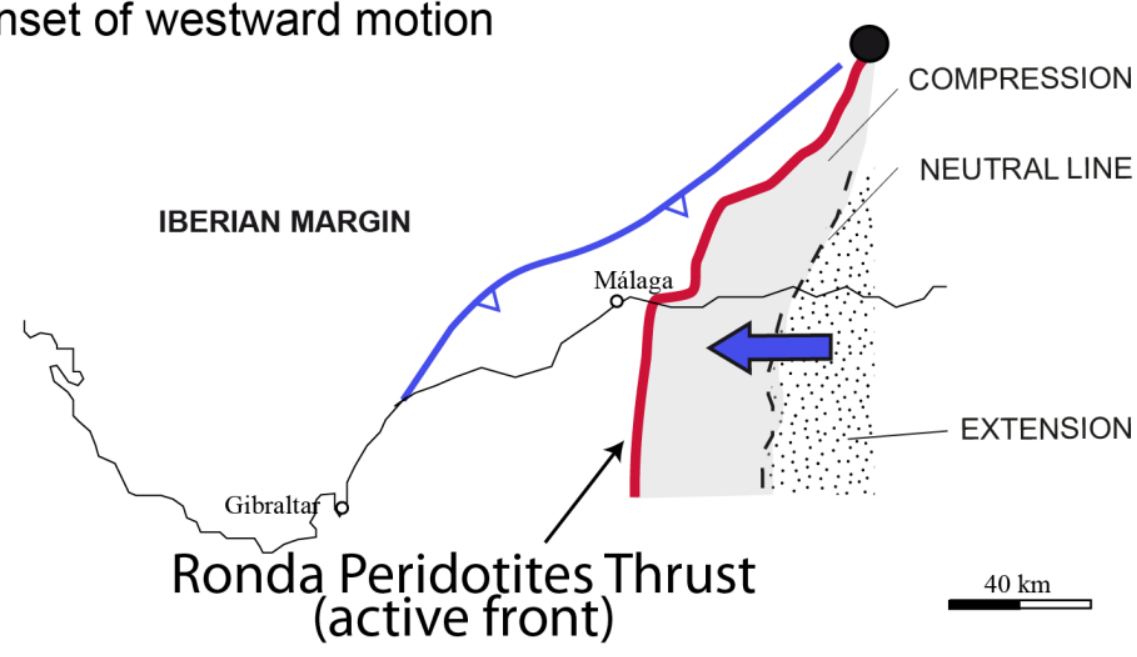

Graphical Abstract 


\section{Highlights}

- westward motion of the Alboran Domain during Lower Miocene

- coeval normal, thrust and strike-slip faults develop under simple shear regime

- major E-W strike-slip corridors act as Lower Miocene lateral ramps

- Lower Miocene slab tearing in the Western Betics 